\title{
Considering the future of anthropogenic gas-phase organic compound emissions and the increasing influence of non-combustion sources on urban air quality
}

\author{
Peeyush Khare ${ }^{1}$ and Drew R. Gentner ${ }^{1,2}$ \\ ${ }^{1}$ Department of Chemical and Environmental Engineering, Yale University, New Haven, CT 06511, USA \\ ${ }^{2}$ SEARCH (Solutions for Energy, Air, Climate and Health) Center, Yale University, New Haven, CT 06511, USA
}

Correspondence: Drew R. Gentner (drew.gentner@yale.edu)

Received: 17 August 2017 - Discussion started: 23 August 2017

Revised: 6 March 2018 - Accepted: 27 March 2018 - Published: 20 April 2018

\begin{abstract}
Decades of policy in developed regions has successfully reduced total anthropogenic emissions of gas-phase organic compounds, especially volatile organic compounds (VOCs), with an intentional, sustained focus on motor vehicles and other combustion-related sources. We examine potential secondary organic aerosol (SOA) and ozone formation in our case study megacity (Los Angeles) and demonstrate that non-combustion-related sources now contribute a major fraction of SOA and ozone precursors. Thus, they warrant greater attention beyond indoor environments to resolve large uncertainties in their emissions, oxidation chemistry, and outdoor air quality impacts in cities worldwide. We constrain the magnitude and chemical composition of emissions via several bottom-up approaches using chemical analyses of products, emissions inventory assessments, theoretical calculations of emission timescales, and a survey of consumer product material safety datasheets. We demonstrate that the chemical composition of emissions from consumer products as well as commercial and industrial products, processes, and materials is diverse across and within source subcategories. This leads to wide ranges of SOA and ozone formation potentials that rival other prominent sources, such as motor vehicles. With emission timescales from minutes to years, emission rates and source profiles need to be included, updated, and/or validated in emissions inventories with expected regional and national variability. In particular, intermediate-volatility and semi-volatile organic compounds (IVOCs and SVOCs) are key precursors to SOA, but are excluded or poorly represented in emissions inventories and exempt from emissions targets. We present an expanded framework for classifying VOC, IVOC, and SVOC emis-
\end{abstract}

sions from this diverse array of sources that emphasizes a life cycle approach over longer timescales and three emission pathways that extend beyond the short-term evaporation of VOCs: (1) solvent evaporation, (2) solute off-gassing, and (3) volatilization of degradation by-products. Furthermore, we find that ambient SOA formed from these noncombustion-related emissions could be misattributed to fossil fuel combustion due to the isotopic signature of their petroleum-based feedstocks.

\section{Introduction}

Anthropogenic emissions of gas-phase organic compounds, including volatile organic compounds (VOCs), are of direct concern as toxic or carcinogenic air pollutants in indoor and outdoor environments (Cohen et al., 2005; Nazaroff and Weschler, 2004; Weschler and Nazaroff, 2008). Often they are more important for air quality as reactive precursors to the formation of outdoor tropospheric ozone and secondary organic aerosol (SOA) as well as indoor SOA and thus play a central role in the elevated mortality and morbidity rates caused by fine-mode particulate matter (i.e., $\mathrm{PM}_{2.5}$ ) and ozone in both developed and developing regions (Destaillats et al., 2006; Jerrett et al., 2009; Lim et al., 2012; Nazaroff and Weschler, 2004; Pope and Dockery, 2006; Sarwar et al., 2004; Singer et al., 2006; Weschler, 2011). In urban and downwind areas globally, $20-70 \%$ of $\mathrm{PM}_{2.5}$ is organic aerosol (OA), with SOA comprising $58 \%$ of OA in 
urban areas and $82 \%$ downwind on average (Zhang et al., 2007).

Yields of SOA and ozone are strongly dependent on precursor molecular size, volatility, structure, and moieties and functionalities, as well as environmental conditions (Gentner et al., 2012; Kroll and Seinfeld, 2008). SOA models have struggled to reproduce observations due to incomplete knowledge on SOA precursors and their sources (Hallquist et al., 2009; Kroll and Seinfeld, 2008). Gas-phase organic compound measurements and emissions data have historically focused on VOCs (i.e., $\mathrm{C}_{2}-\mathrm{C}_{12}$ alkanes and VOCs with equivalent volatilities), but research has demonstrated the prevalence and importance of larger, intermediate-volatility and semi-volatile organic compounds (IVOCs and SVOCs, respectively; Gentner et al., 2012; Kroll and Seinfeld, 2008; Robinson et al., 2007; Zhao et al., 2014). With greater SOA mass yields, IVOCs and SVOCs are key for modeling and mitigating SOA but are less studied due to measurement difficulties (Gentner et al., 2012; Goldstein and Galbally, 2007). While their emissions from motor vehicles have received more attention, emissions from most other sources are poorly constrained.

In recent history, motor vehicles, power plants, and residential combustion have been the dominant drivers of detrimental air quality (e.g., VOCs, nitrogen oxides $\left(\mathrm{NO}_{x}\right)$, $\mathrm{PM}_{2.5}$, ozone, sulfur dioxide $\left.\left(\mathrm{SO}_{2}\right)\right)$, with automobiles dominating anthropogenic VOC emissions in major cities (Genther et al., 2017; Hao et al., 2007; McDonald et al., 2013, 2015; Warneke et al., 2012; Zhou et al., 2003). Yet due to the success of combustion-related emissions control policies over the past 60 years, motor vehicle VOC (and other pollutant) emission factors have decreased by orders of magnitude en route to today's diesel and gasoline vehicles, albeit with some recent on-road diesel $\mathrm{NO}_{x}$ compliance issues (Hao et al., 2007; Kirchstetter et al., 1999; US Environmental Protection Agency, 2011; Warneke et al., 2012). In no other place has this been more studied than Los Angeles, CA where $\mathrm{PM}_{2.5}$ and ozone still exceed standards and OA comprises $41 \%$ of $\mathrm{PM}_{1}, 66 \%$ of which is SOA (Hayes et al., 2013; Warneke et al., 2012). Recent work has suggested that motor vehicle emissions in LA cannot fully explain observations of reactive precursors and SOA (Ensberg et al., 2014; Hayes et al., 2015; McDonald et al., 2015; Zhao et al., 2014). In LA and beyond, the role of motor vehicles in degrading air quality will decline further with the newest on-road emissions standards (e.g., Tier 3/LEV-III, Euro 6/VI; Fig. 1), the use of electric-powered vehicles, and stricter regulations on emissions from off-road vehicles and other engines (Gentner et al., 2017; Giannouli et al., 2011; Gordon et al., 2013; Platt et al., 2014; Tessum et al., 2014; Weiss et al., 2011).

The main objective of this paper is to evaluate anthropogenic sources of gas-phase organic compounds that are gaining prominence as motor vehicles and other combustionrelated sources become cleaner in the developed and developing world. We demonstrate that consumer products as well
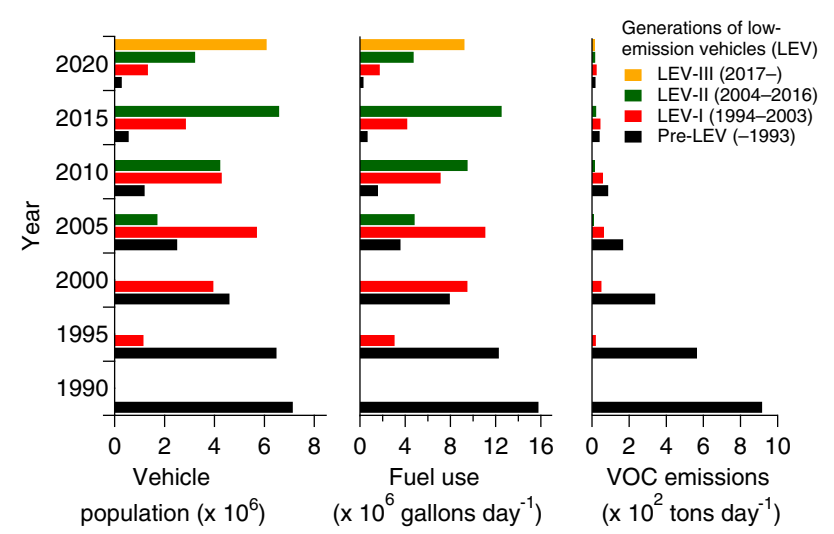

Figure 1. Characteristic evolution and modernization of in-use motor vehicle fleets. Trends in motor vehicle population, fuel use, and VOC emissions for model years conforming to pre-LEV, LEVI, LEV-II, and LEV-III emissions standards in California's South Coast Air Basin for 1990-2020 from CARB's EMFAC database (California Air Resources Board, 2014).

as commercial and industrial products, processes, and materials are important, widely distributed area sources of VOCs, IVOCs, and SVOCs with variable source profiles, making their emissions and impacts difficult to observe and constrain. Our demonstration builds on relevant indoor air quality studies observing emissions and substantial SOA formation from ozone-initiated reactions with emissions from consumer products, building materials, and cleaning products (Chang et al., 2011; Destaillats et al., 2006; Gold et al., 1978; Lewis, 2001; Mitro et al., 2016; Nazaroff and Weschler, 2004; Singer et al., 2006; Weschler, 2011; Weschler and Nazaroff, 2008; Wilke et al., 2004), as well as secondary emissions from oxidative degeneration of indoor paints, varnishes, and materials (Knudsen et al., 1999; Poppendieck et al., 2007a, b; Salthammer and Fuhrmann, 2007).

We outline a holistic framework to assist future research in the field and then use a multi-dataset approach to constrain emissions, which includes the most detailed emissions inventory available, laboratory analysis of product composition, a survey of consumer product material safety datasheets (MSDSs), and calculations of emissions timescales from theory. Specifically, we (a) evaluate the pathways, chemical composition, and magnitude of VOC, IVOC, and SVOC emissions from prominent types of products, processes, and materials; (b) calculate their potential to form SOA and ozone; and (c) compare their emissions and potential air quality impacts to other prominent sources. We identify major knowledge gaps in emission rates and composition, including IVOCs and SVOCs, which we explore via two examples: pesticides and asphalt-related emissions. 


\section{Defining a comprehensive framework for non-combustion-related emissions}

There is a wide body of work on some aspects of emissions from products, processes, and materials in indoor or outdoor environments, but outdoor-focused emissions inventories are mostly focused on evaporative emissions of VOC solvents at the time of application. Here we outline the current scope of emissions and expand on it to define a comprehensive framework to guide future studies on this class of emissions.

\subsection{Volatility}

Emissions of gas-phase organic compounds can and should be differentiated by their volatility into VOCs, IVOCs, and SVOCs or further by their $n$-alkane-equivalent volatility (Murphy et al., 2014). One can broadly refer to compounds emitted from products and processes as product- and processrelated emissions.

\subsection{Source categories}

While the spectrum of sources is very diverse, they are often grouped by use. The following source categories are consistent with the most detailed VOC inventories for consumer products, but are extended (shown with * below) to incorporate a broader array of materials and products, including those used in commercial and industrial processes:

- paints (indoor and outdoor),

- industrial adhesives,

- consumer adhesives,

- sealants,

- pesticides (consumer and agricultural),

- general cleaning products,

- targeted cleaners,

- personal products (e.g., beauty and hygiene),

- building materials (e.g., carpeting, flooring, insulation, wood, gypsum),*

- furnishings (e.g., furniture), ${ }^{*}$

- paving and roofing asphalt-related materials, and

- solid consumer products and packaging (e.g., plastics, elastomers) and their additives (e.g., plasticizers, flame retardants).*

However, the volatility range of most of the existing categories needs to be expanded to completely include IVOCs and SVOCs. We discuss IVOC- and SVOC-containing pesticides and asphalt-related products and processes as examples that are not sufficiently included in inventories (see
Sect. 4.1.3). Note: we exclude gasoline evaporation (from vehicles or fuel stations) and fossil fuel extraction and processing given their close connection to combustion. We briefly discuss food-derived cooking emissions for comparison, which are important and classified separately.

\subsection{Emission pathways}

We propose three general pathways of product- and processrelated emissions:

1. evaporation of solvent from a product while it is in storage, being used, or during a process;

2. volatilization of solute or active compounds from an applied coating, a solid product, or material (i.e., offgassing); and

3. volatilization of by-products from the degradation or transformation of solute or active compounds or a solid product or material.

The first is the principal pathway previously considered and often occurs over faster timescales (minutes-days) from liquids like cleaners, paints, and other solvents. The second acts over longer timescales (weeks-years), is not always included in inventories, and is a key potential source of IVOCs and SVOCs (see Sect. 4.1.3). SVOC pesticides, flame retardants, and off-gassing plastics are examples studied for indoor air quality (Batterman et al., 2009; Brodzik et al., 2014; Clausen et al., 2004; Faber et al., 2013; Kemmlein et al., 2003; Lewis, 2001; Wensing et al., 2005; Weschler and Nazaroff, 2008). The third is due to the generation of degradation by-products via thermal or photochemical stress, exposure to oxidants (i.e., $\mathrm{OH}, \mathrm{O}_{3}$, or $\mathrm{NO}_{3}$ ), or other reactive chemical processes. These may have longer emission timescales depending on oxidant concentrations and the chemical and physical properties of degradation precursors. These emissions are largely understudied with the exception of asphalt-related emissions and the ozonation of indoor materials (Poppendieck et al., 2007a, b; Salthammer and Fuhrmann, 2007; Toftum et al., 2008).

\subsection{A life cycle approach}

Emissions during application or immediate use are most commonly studied, but many emissions related to products, process, and materials occur over much longer timescales. In the future, emissions studies need to include all three potential emissions pathways across the full life cycles of the following:

$$
\begin{aligned}
& \text { - storage, } \\
& \text { - transport, } \\
& \text { - application, } \\
& \text { - curing, }
\end{aligned}
$$




$$
\begin{aligned}
& \text { - active use, } \\
& \text { - weathering, } \\
& \text { - restoration, and } \\
& \text { - removal and disposal. }
\end{aligned}
$$

There are too many facets within the life cycles of each source category to discuss in this paper, but our case study on asphalt-related emissions in Sect. 4.1.3 demonstrates several aspects. Production methods are not explicitly included here since they may fall under the purview of industrial point sources, but with small, distributed production it may be appropriate to consider the industrial and/or commercial processes as area-wide sources. Chemical transformations of materials or products across their lifetimes need to be considered since they can influence the chemical composition and rates of emissions. For example, transformations can occur during a wide variety of in-use conditions or during the storage of unused or partially used products and materials, both of which can be over long storage periods in a variety of environmental conditions. Application methodology is a determining factor in both emission rates and composition during application. For example, common methods include direct liquid application or aerosolization, either via a pressurized can or a nozzle and air compressor, and aerosolization provides a direct emission pathway for all components and the subsequent evaporation of aerosol droplets. Finally, emissions in latter parts of life cycles (i.e., weathering, deterioration, restoration, removal, and disposal) all need to be considered.

\section{Methods}

We constrain the magnitude, chemical composition, and potential air quality impacts of emissions using multiple bottom-up approaches: chemical characterization of a selection of consumer products via gas chromatography-mass spectrometry and carbon isotope mass spectrometry; a detailed assessment of emissions inventories and estimation of source contributions to potential SOA and ozone formation; theoretical calculations of emission timescales; and a survey of reported chemical composition in consumer product MSDSs. Details on the emission timescale calculations can be found in Appendix B, and other additional methods details pertaining to potential SOA and ozone estimation can be found in the Supplement.

\subsection{Chemical speciation of consumer products}

We selected 17 consumer products across a range of product types with attention to those with unresolved alkane or aromatic mixtures (Table 1). Top-selling products from major commercial providers were selected in order to make a realistic assessment of products that are currently in significant public use and to avoid biasing the analysis towards less-common products. With a limited sample size, only one water- and one ethanol-based product were included. Diluted

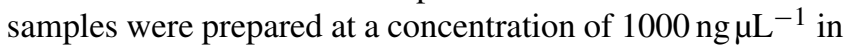
either hexane or toluene depending upon the product composition provided in their MSDS. The chemical composition of the emittable fraction of products was determined using gas chromatography with electron ionization mass spectrometry (GC-EI-MS; Agilent 7890B/5977). A $1 \mu \mathrm{L}$ syringe (Hamilton) was used to directly inject the sample onto the $\mathrm{GC}$ column through an inlet held at $320^{\circ} \mathrm{C}$. During each injection, the column was initially held at $40^{\circ} \mathrm{C}$ for $2 \mathrm{~min}$, then ramped at $10^{\circ} \mathrm{Cmin}^{-1}$ to $325^{\circ} \mathrm{C}$, and lastly held at $325^{\circ} \mathrm{C}$ for $5 \mathrm{~min}$. Mass spectra of background subtracted individual ion peaks were used to identify compounds in a sample using the NIST mass spectra library. Calibration curves were drawn for five different concentrations of authentic standards (AccuStandard) for diesel range alkanes $\left(\mathrm{C}_{10}-\mathrm{C}_{28}\right)$, purgeable aromatics, and terpenes. The emittable organic fraction of raw products is defined by volatility and approximated as VOCs + IVOCs via our chemical analysis and reported MSDS data (note: SVOCs are excluded in this analysis to focus on compounds that are fully partitioned to the gas-phase at equilibrium under typical conditions). A carbon isotopic analysis was also carried out at the Keck Carbon Cycle Accelerator Mass Spectrometer (AMS) facility at UC Irvine to measure carbon-14 (\%o $\left.\Delta^{14} \mathrm{C}\right)$ and carbon-13 $\left(\% \circ \mathrm{d}^{13} \mathrm{C}\right)$ relative to carbon-12 via a $0.5 \mathrm{MV}$ Compact AMS (National Electrostatics Corp.) and estimate the fossil carbon content in individual products.

\subsection{Urban emissions inventories}

We used the California Air Resources Board (CARB) Almanac emissions inventory and the US EPA SPECIATE 4.4 source profiles to generate the total and compound-specific emissions for California and Los Angeles (Cox et al., 2013; US Environmental Protection Agency, 2014). The CARB emissions inventory is the most detailed available with respect to source categories and basin-level rates. Los Angeles is our case study megacity given its historical role in air quality research and policy with a multi-decadal record of emissions data, ambient measurements, field campaigns, and publications (Bishop and Stedman, 2008; Fortin et al., 2005; Neligan, 1962; Warneke et al., 2012). In addition, the US National Emissions Inventory and emission inventories from the Global Emissions Initiative (GEIA) were used for nationwide and worldwide comparison of VOC emissions, respectively, from solvents and on-road motor vehicles.

We estimated total daily potential ozone and SOA formation in greater Los Angeles from the product- and processrelated emissions included in the CARB inventory. Values were also calculated for exhaust and evaporative emissions from on-road motor vehicles using CARB's Emission Fac- 
Table 1. Composition and emittable fraction of 12 commercially available consumer products and the results of their carbon isotope analysis. Please see Table S1 for detailed mass distribution profiles and Table S7 for detailed carbon isotopic analysis results ${ }^{\mathrm{k}}$.

\begin{tabular}{|c|c|c|c|c|c|c|}
\hline Product name & $\begin{array}{r}\text { Percent fossil } \\
\text { origin }\end{array}$ & $\begin{array}{l}\text { IVOC } \\
\text { content }\end{array}$ & $\begin{array}{r}\text { Aromatic } \\
\text { content }\end{array}$ & $\begin{array}{r}\text { Emittable } \\
\text { fraction }\end{array}$ & $\begin{array}{r}\mathrm{d}^{13} \mathrm{C} \\
(\% \circ)\end{array}$ & $\begin{array}{r}\Delta^{14} \mathrm{C} \\
(\% \circ)\end{array}$ \\
\hline Naphtha cleaner & $>99 \%$ & - & - & $100 \%$ & $-29.0 \pm 0.1$ & $-999.4 \pm 0.5$ \\
\hline Nonpolar solvent & $>99 \%$ & - & $93 \%$ & $100 \%$ & $-27.4 \pm 0.1$ & $-998.5 \pm 0.5$ \\
\hline Fogging insecticide $\mathrm{m}^{\mathrm{m}}$ & $>99 \%$ & $95 \%$ & - & $95 \%$ & $-26.7 \pm 0.1$ & $-999.1 \pm 0.5$ \\
\hline Semigloss furniture coating & $56 \%$ & - & $6 \%$ & $30 \%$ & $-29.9 \pm 0.1$ & $-565.4 \pm 0.7$ \\
\hline Multipurpose solvent ${ }^{\mathrm{a}}$ & $>99 \%$ & - & - & $100 \%$ & $-30.6 \pm 0.1$ & $-997.8 \pm 0.7$ \\
\hline Furniture coating ${ }^{\mathrm{m}}$ & $65 \%$ & - & $1 \%$ & $40 \%$ & $-30.2 \pm 0.1$ & $-650.0 \pm 0.6$ \\
\hline Roof paint ${ }^{b}$ & $>98 \%$ & - & - & - & $-22.7 \pm 0.1$ & $-985.0 \pm 0.5$ \\
\hline Sealant ${ }^{\mathrm{c}, 1}$ & $97 \%$ & $0.77 \%$ & $21 \%$ & $25 \%$ & $-27.4 \pm 0.1$ & $-969.9 \pm 0.5$ \\
\hline Paint thinner ${ }^{\mathrm{m}}$ & $>99 \%$ & $2 \%$ & $3 \%$ & $100 \%$ & $-29.1 \pm 0.1$ & $-999.7 \pm 0.5$ \\
\hline Asphalt coating ${ }^{\mathrm{d}, 1}$ & $>99 \%$ & $4 \%$ & $3 \%$ & $25 \%$ & $-27.6 \pm 0.1$ & $-994.8 \pm 0.6$ \\
\hline Detergent $\mathrm{e}^{\mathrm{e}}$ & $81 \%$ & $3.5 \%$ & $4 \%$ & $25 \%$ & $-27.9 \pm 0.1$ & $-807.8 \pm 0.6$ \\
\hline General purpose cleaner ${ }^{\mathrm{f}}, \mathrm{m}$ & $81 \%$ & $1 \%$ & - & $3 \%$ & $-27.7 \pm 0.1$ & $-811.1 \pm 1.3$ \\
\hline Multipurpose lubricant & - & $39 \%$ & - & $97 \%$ & - & - \\
\hline Aerosol coating product $\mathrm{g}, \mathrm{m}$ & - & - & $12 \%$ & $17 \%$ & - & - \\
\hline Flashing cement ${ }^{\text {h, } 1}$ & - & $0.2 \%$ & $3.5 \%$ & $27 \%$ & - & - \\
\hline Crawling insecticide $1^{\mathrm{i}, \mathrm{m}}$ & - & $20 \%$ & - & $20 \%$ & - & - \\
\hline Crawling Insecticide $2^{\mathrm{j}, \mathrm{m}}$ & - & $8 \%$ & - & $8 \%$ & - & - \\
\hline
\end{tabular}

a Largely consists of acetone ( $80 \%$ ) with the rest as cyclotetrasiloxanes and aryl halides.

b Water-based product. Other components include titanium dioxide, silica, and aluminum hydroxide.

${ }^{\mathrm{c}}$ Largely consists of petroleum asphalt, clays, and cellulose.

d Largely consists of petroleum asphalt.

e $46 \%$ of the emittable fraction (EF) consists of mostly esters, $70 \%$ of which have fewer than 12 carbon atoms. Terpenes including limonene, eucalyptol, and $\alpha$-terpineol form $37 \%$ of the EF.

${ }^{\mathrm{f}}$ Water-based product, with water excluded from emittable fraction. Also has terpenes including camphene, d3-carene, $\alpha$-pinene, linalool, and

$\delta$-limonene. $60 \%$ of terpene fraction is $\delta$-limonene.

$\mathrm{g}$ Contains $35 \%$ acetone and $25 \%$ hydrocarbon propellants not included in the EF. * $25 \%$ of EF is $75 \%$ acetate $+25 \%$ ketones.

${ }^{\mathrm{h}}$ Largely consists of petroleum asphalt, kaolin, cellulose, and aluminum magnesium silicate.

i Contains $15 \%$ hydrocarbon propellants not included in the EF.

j Contains $25 \%$ hydrocarbon propellants not include in the EF.

$\mathrm{k}$ Crude oil and plant-derived ethanol were used for multiple reference blanks (Table S8).

${ }^{1}$ Asphalt-related products.

$\mathrm{m}$ Applied as aerosols.

Note: all fractions given in the footnotes refer to the emittable fraction of a product. Emittable fraction is confirmed with MSDS where possible.

tors (EMFAC) model database and literature ozone and SOA yields for each source pathway and low-emission vehicle (LEV) generation (Gentner et al., 2013, 2017; Zhao et al., 2017). Potential ozone formation values are based on maximum ozone incremental reactivity (MOIR) values from the SAPRC-07 inventory (Carter, 2007; Gentner et al., 2013). The very diverse range of compound classes used in products, materials, and processes remain largely understudied with respect to their SOA yields (e.g., esters, siloxanes). Hence, specific literature SOA yields were used wherever possible (Algrim and Ziemann, 2016; Chacon-Madrid et al., 2010; Chan et al., 2010; Gentner et al., 2012; Kwok and Atkinson, 1995; Ng et al., 2006; Pankow and Asher, 2008; Sadezky et al., 2006; Tsimpidi et al., 2010) and estimated for other unstudied compounds without existing SOA yields (see Table S6 for details). SOA yields are estimated at $10 \mu \mathrm{g} \mathrm{OA} \mathrm{m}{ }^{-3}$ in urban, "high- $\mathrm{NO}_{x}$ " conditions (approx. $>5 \mathrm{ppb}$ ). Ozone and SOA yields for each analyzed consumer product and product category are compared to other key sources. The SOA yields provide a conservative, lower estimate of potential SOA without aqueous SOA despite studies showing that aqueous pathways to SOA increase SOA yields for small oxidized precursors or their oxidation by-products (Daumit et al., 2016; Jia and Xu, 2014). For the case study city Los Angeles (and Mexico City), aqueous SOA formation was relatively small during major field studies (Dzepina et al., 2009; Hayes et al., 2015; Washenfelder et al., 2011). However, future work in other cities should consider aqueous SOA given the magnitude of the oxygenated fraction in product- and process-related emissions (see Sect. 4.1.2).

\subsection{Survey of material safety datasheets (MSDS)}

We obtained the MSDS data by surveying a set of 88 MSDS entries from the websites of major home improvement stores focusing on their top-selling products. Five product categories were chosen including paints, adhesives, cleaning products, sealants, and pesticides. Chemical composition information was extracted from the "composition and infor- 
mation on ingredients" section reported in the datasheets. MSDS entries for commercial products frequently report 30 to $60 \%$ of product composition as "proprietary mixtures", so this survey only identifies the presence and establishes general ranges for current product types (Table 2).

\section{Results and discussion}

\subsection{Composition and magnitude of product- and process-related emissions}

The organic compositions of consumer products and commercial and industrial products, materials, and processes are very diverse, which leads to similar diversity in emissions, and further regional and national heterogeneity can be expected. We calculate the magnitude and average chemical composition of emissions from source categories included in the CARB emissions inventory and SPECIATE database (Fig. 2a) with the goal of assessing the distribution of emissions across organic compound classes and product types (i.e., source profiles) in a megacity with the most representative inventory available. We find that the consumer products and the commercial and industrial processes that comprise product- and process-related sources in the inventory are altogether large emitters of a diverse suite of VOCs, but view these results as a lower estimate given likely missing emissions, such as those discussed in Sects. 2 and 4.1.3.

\subsubsection{Chemical composition}

\section{Laboratory analysis of consumer products}

Our results summarized in Table 1 demonstrate the prevalence of non-benzene, single-ring aromatics and $\mathrm{C}_{6}-\mathrm{C}_{12}$ alkane mixtures as solvents and the presence of IVOCs and SVOCs in consumer products. The emittable fraction of products ranged from $3-100 \%$, and the single-ring aromatic and IVOC content ranged from 3.5-93 and 0.77-95\%, respectively. Another key result of this analysis is the frequency of many functionalized aliphatic or aromatic VOCs and IVOCs that are not traditionally measured in atmospheric monitoring (e.g., esters, acetates, siloxanes), which is echoed in the MSDS survey results. More detailed speciation results with a breakdown of alkanes and single-ring aromatic compounds can be found in Table S1 in the Supplement. Validation of real-world product- and process-related emission rates and timescales is necessary to advance the field but will require examining a wide range of products and geographic conditions.

\section{Analysis of emissions inventories}

Figure 3a shows the estimated overall composition of product- and process-related emissions in Los Angeles averaged over the years 2005 to 2020 determined by combin-
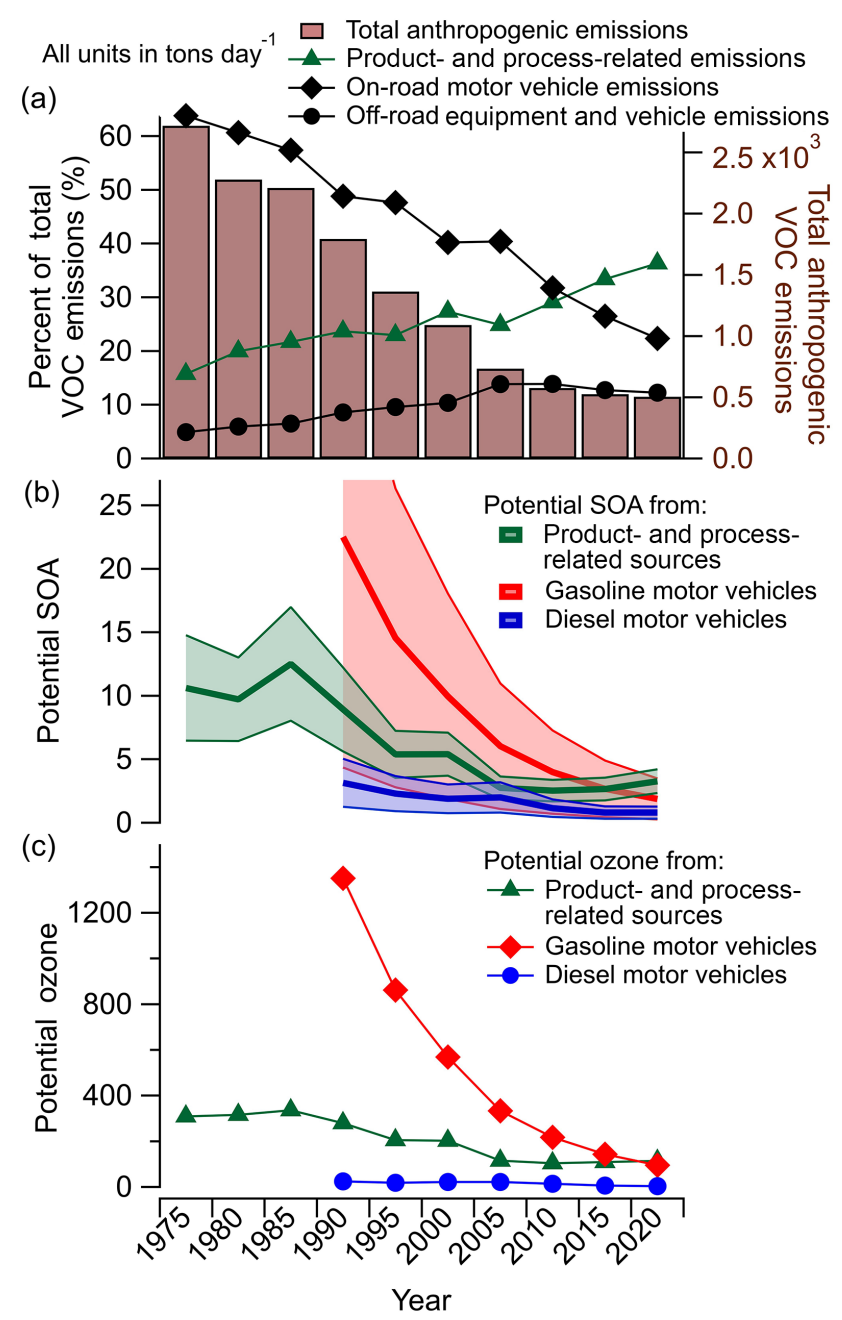

Figure 2. Emissions and potential air quality impacts of productand process-related sources and motor vehicles over time in the South Coast Air Basin (i.e., Los Angeles). (a) Total anthropogenic VOC emissions (excluding ethane). (b) Potential SOA from product- and process-related emissions compared to on-road motor vehicles, with uncertainties based on the ranges of compound-classspecific SOA yields. (c) Ozone formation potential via compoundspecific maximum ozone incremental reactivity values (SAPRC, no uncertainty given). All units are in $\mathrm{tday}^{-1}$ for panels $(\mathbf{a}-\mathbf{c})$. Product- and process-related results are produced using CARB emissions data and EPA source profiles; see Methods for further detail. Note: none of the panels include VOCs, IVOCs, or SVOCs from products and processes that we identify in Sects. 2 and 4 as missing from emissions inventories, but SOA and ozone formation from motor vehicle emissions does include IVOCs and SVOCs. Maximum potential SOA from gasoline vehicles in 1990 was $\sim 41 \mathrm{tday}^{-1}$ (off graph). Pre-1990 potential SOA and ozone for motor vehicles is excluded due to the lack of fleet-resolved data.

ing SPECIATE source profiles with the CARB emissions inventory for the South Coast Air Basin (SoCAB). Alcohols and miscellaneous emissions together make up $50 \%$ of the total product- and process-related emissions with ethanol as 
Table 2. Analysis of material safety datasheets commercially available with products.

\begin{tabular}{lllll}
\hline Product category & $\begin{array}{l}\text { Fraction of products } \\
\text { with aromatic content }\end{array}$ & $\begin{array}{l}\text { MSDS aromatics \% wt. } \\
\text { mean (range) }\end{array}$ & $\begin{array}{l}\text { Fraction of products with } \\
\text { IVOC and SVOC content }\end{array}$ & $\begin{array}{l}\text { MSDS IVOCs and SVOCs } \\
\% \text { wt. mean (range) }\end{array}$ \\
\hline Paints & $0 \%$ & 0 & $24 \%^{\mathrm{a}}$ & $2.5(1-5)$ \\
Adhesives & $27 \%$ & $8(1-30)$ & $7 \%^{\mathrm{b}}$ & $20(10-30)$ \\
Cleaning products & $8 \%$ & $5(1-10)$ & $23 \%^{\mathrm{c}}$ & $3.5(1-7)$ \\
Sealants & $53 \%$ & $9(1-30)$ & $7 \%^{\mathrm{d}}$ & $4(1-10)$ \\
Pesticides & NS & NS & NS & NS \\
\hline
\end{tabular}

\footnotetext{
${ }^{\text {a }}$ Consists of benzoates. $\log K_{\mathrm{OA}}=7.75$, which puts them in the IVOC range.

${ }^{\mathrm{b}}$ Does not include potential emissions from petroleum asphalt, which on average constitutes $36 \%$ in $13 \%$ of the surveyed products. $50 \%$ of products contain $38 \%$ limestone on average.

${ }^{c}$ Includes $\mathrm{C}_{9}-\mathrm{C}_{14}$ ethoxylated alcohols.

d Does not include potential emissions from petroleum asphalt, which on average constitutes $40 \%$ in $33 \%$ of the surveyed products. $60 \%$ of products contain $36 \%$ limestone on average.

e $20 \%$ of MSDSs include "nonhazardous" or "proprietary" component in composition ranging from 60-100\%.

${ }^{\mathrm{f}}$ MSDSs do not present sufficient information on the composition of pesticides (NS: not sufficient).
}

one of the largest individual species emitted, which is consistent with SoCAB ethanol observations that were substantially greater than what would be expected with gasoline vehicles as the only source (de Gouw et al., 2012). $70 \%$ of the miscellaneous emissions are made up of mineral spirits whose composition varies greatly with application but are generally comprised of acyclic and cyclic $\mathrm{C}_{7-12}$ alkanes with variable amounts of aromatic content. The remaining $30 \%$ includes unresolved asphalt mixtures, oxygenates, fragrances, and undefined petroleum distillates, oils, and spirits, some of which also fall into the IVOC and SVOC categories discussed below. Single-ring aromatics are estimated at $13 \%$ of total emissions with a mix of $43 \%$ toluene, $38 \% \mathrm{C}_{8}, 3 \%$ $\mathrm{C}_{9}$, and $1.5 \% \mathrm{C}_{10}$ aromatics, with minor $\mathrm{PAH}$ emissions. Carbonyls represent $10 \%$ of total emissions, $36 \%$ of which is acetone. Anthropogenic terpenoid emissions in the inventory, while highly reactive, are small relative to other sources and biogenic contributions (see Sect. S4 in the Supplement).

Figure $3 \mathrm{~b}$ shows the distribution of organics in the SoCAB emissions inventory from major product- and process-related source categories. Paints emerged as the highest VOC emitter, $\sim 21 \%$ of which is single-ring aromatics (Figs. 3b and S4 in the Supplement). Targeted cleaners, pesticides, and general cleaners were the next largest source types in the inventory. A more detailed breakdown of emissions broken up by source category and compound class can be found in Table S3. We used the EPA SPECIATE database for source profiles in this study, which had a national scope, some inclusion of IVOCs and SVOCs, and greater chemical detail (i.e., number of species). We examined changes in the chemical speciation of total emissions with CARB's 2010 adjustment to SPECIATE in the final years of our study period. We found minor differences in the overall emissions (Fig. S5) that are largely attributable to changes in the assignment of unspeciated (i.e., miscellaneous) VOC, IVOC, and SVOC emissions that do not affect our conclusions. Differences in potential SOA and ozone in the SoCAB for 2010-2020 (Sect. 4.2) are not clear due to uncertainties in these changes to unspeciated assignments and the uncertainties in SOA yields.

\section{MSDS survey}

As summarized in Table 2, the greatest single-ring aromatic content was observed in adhesives $(8 \%)$ and sealants $(9 \%)$, while the 30 surveyed paints did not have aromatic VOC content in contrast to the SPECIATE source profiles (Figs. 3b and S4). In comparison, the chemical speciation of 42 major products categorized as "solvents" (across $\mathrm{C}_{6-13}$ ) in 2002 reports a wide range of total aromatic content (0-100\%) and an average of $41 \%( \pm 46 \%)$ with the remainder comprised of acyclic and cyclic alkanes (Censullo et al., 2002). Differences when compared to our present-day laboratory and MSDS paint speciation show reductions in aromatic content due to increasingly stringent regulations in the US. However, for other locations, it highlights the likely continued prevalence of single-ring aromatics in solvents, especially for developing regions. We also found that MSDSs did not report IVOC and SVOC content in the composition of pesticides. However, we observed 8-95\% IVOC content in the emittable fraction of the pesticide samples analyzed in our laboratory. For all of the product categories examined, especially for pesticides, the amount of compositional information provided by the MSDSs is limited and hinders our ability to constrain the average aromatic or IVOC and SVOC content since compounds outside the VOC range are often not disclosed due to proprietary claims or regulatory exemptions, and where provided all compound concentrations are usually provided as a wide range. For example, under "fragrance exemptions" VOCs and IVOCs are often not disclosed and can even be labeled as "VOC free".

\subsubsection{Emission rates}

While motor vehicles are still major sources in developed regions, their total gas-phase organic compound emissions 
(a)

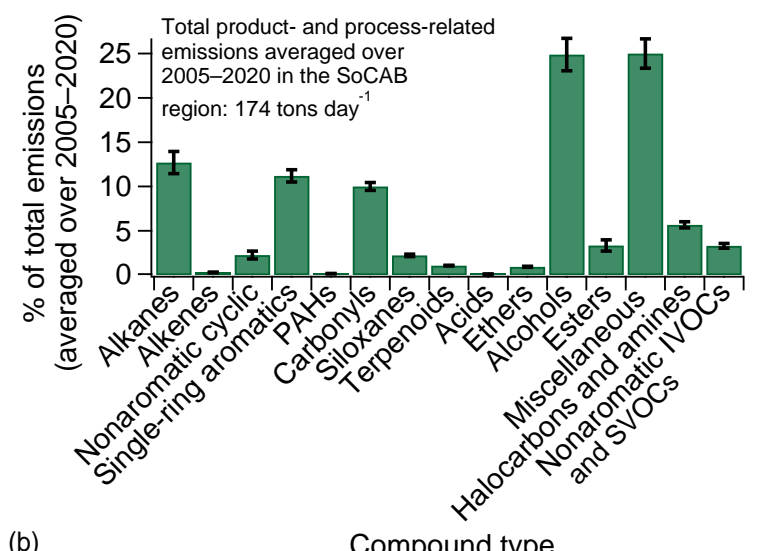

(b)

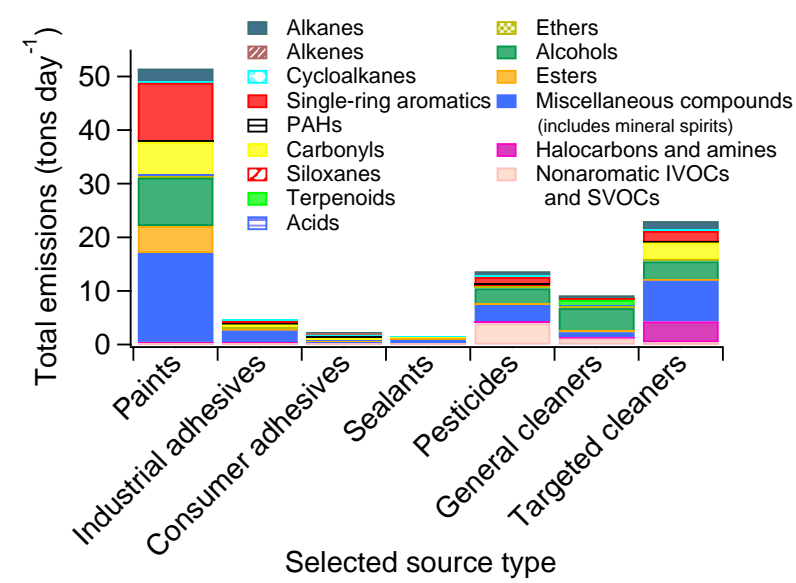

Figure 3. Average emissions from product- and process-related sources for 2005-2020 based on data from CARB inventory and SPECIATE database as a function of (a) compound class (shown with standard deviations) and (b) major product- and processrelated source categories in the inventory (values in Table S3). "Miscellaneous" contains $70 \%$ mineral spirits $\left(\mathrm{C}_{7-12}\right.$ hydrocarbons). IVOCs and SVOCs do not include an estimate of the missing emissions identified in Sects. 2 and 4.

have been gradually declining with the continued implementation of stricter emissions standards (Gentner et al., 2017), increasing the relative importance of other sources (Figs. 1, 2a). At a global scale, the MACCity and ACCMIP emissions inventories estimate global solvent-related VOC emissions of $15 \mathrm{Tg} \mathrm{yr}^{-1}$ in 2000 and year-over-year increases since 1960 (speciated by aromatics, $\mathrm{C}_{6+}$ alkanes, ketones, alcohols, and other VOCs), and emissions of aromatics from solvents are expected to outweigh those from transportation in 2020 (7.5 vs. $6.7 \mathrm{Tg} \mathrm{yr}^{-1}$; GEIA, 2017). The 2014 US National Emissions Inventory (NEI) data report that VOC emissions from solvent-related sources are just $25 \%$ less $\left(300 \mathrm{tday}^{-1}\right)$ than those from on-road mobile sources nationally, while they exceed on-road emissions by $25 \%\left(21 \mathrm{tday}^{-1}\right)$ in California (US Environmental Protection Agency, 2011). Figure S1 shows California's statewide bi-decadal emissions estimates from CARB in which product- and process-related VOCs will reach $450 \mathrm{tday}^{-1}$ in 2020, exceeding motor vehicles by 116 tday $^{-1}$. A similar picture may emerge in developing nations as the control of motor vehicle emissions is greatly accelerated by the advancements and knowledge of developed nations such that emission standards in major emerging economies employ either US or EU policies and are generally only one generation behind (Kodjak, 2015). International studies over the past 2 decades show highly varying contributions $(\sim 5-45 \%)$ to the total anthropogenic VOC emissions from just "solvent" use at both regional and national scales (summarized in the Supplement; van den Born et al., 1991; Caserini et al., 2004; Chen et al., 2009; Deguillaume et al., 2008; Lu et al., 2007; Markakis et al., 2009; Menut, 2003; Nielsen et al., 2008; Piccot et al., 1992; Song et al., 2007; US Environmental Protection Agency and Office of Air Quality Planning and Standards, 1991).

Emissions inventory data for Los Angeles demonstrate that anthropogenic emissions have consistently decreased over the last 4 decades (Fig. 2a), which is consistent with ambient observations (1960-2010; Warneke et al., 2012). As the contribution of on-road motor vehicles to total anthropogenic emissions has declined, product- and process-related sources have become a major contributor of VOCs. Based on the CARB emissions inventory, contributions of productand process-related sources are the largest single contributor of VOC emissions in the basin and state (Figs. 2a and S1) and are growing with population (i.e., increased in-basin usage). While consumption volume is low compared to combustion fuels, emission factors are higher given that most of the volatile components are emitted, whereas fuels are burnt at $\geq 99 \%$ efficiency. Yet, no region can be fully representative of product- and process-related emissions on a larger scale, and regional and/or national specifics will influence the magnitude and composition of emissions. For example, California's extensive regulations will modify the composition of products sold in CA and likely elsewhere in the US.

\subsubsection{Emissions of intermediate- and semi-volatile organic compounds (IVOCs and SVOCs)}

Despite representing only a small to moderate amount of emissions, IVOCs and SVOCs from motor vehicles are key precursors to urban SOA (Gentner et al., 2012; Robinson et al., 2007). Similarly, we conclude that consumer products and commercial or industrial products, processes, and materials are also large sources of unspeciated IVOCs and SVOCs, some of which are included in the CARB inventory, while there is evidence that some other source pathways are not.

Many common products and materials (e.g., pesticides, fragrances, foams, plastics) have IVOCs or SVOCs that partition to reach equilibrium and evaporate over long timescales (Fig. 4; Batterman et al., 2009; Clausen et al., 2004; Mitro 


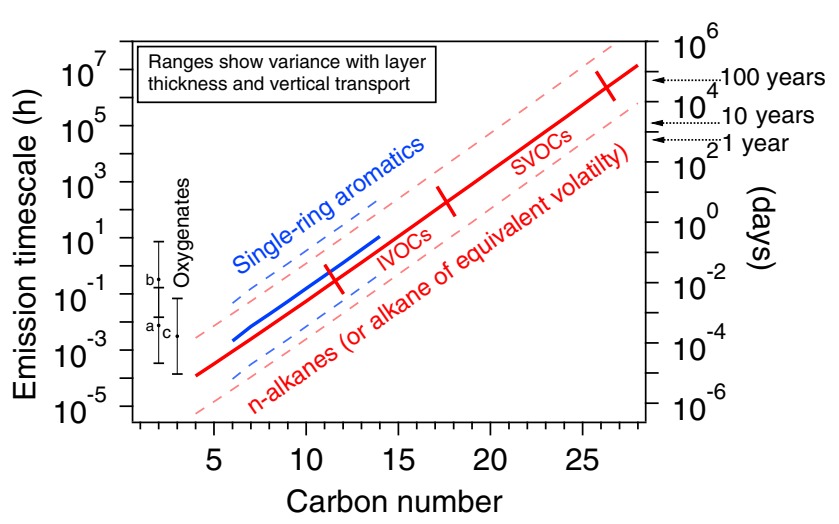

Figure 4. Emission timescales for single-ring aromatics, alkanes, and prominent solvents: ethanol (a), ethylene glycol (b), and acetone (c). Based on applied layers of $0.01-1 \mathrm{~mm}$ and vertical transport coefficients for neutral and stable outdoor conditions (10$50 \mathrm{~m} \mathrm{~h}^{-1}$ ), with longer timescales in indoor environments or thicker layers (e.g., asphalt, building materials). The left axis is reproduced on the right in days. Timescales are limited by gas-phase transport from the surface, but absorption into polymeric or porous substrates could extend timescales (Weschler and Nazaroff, 2008). Volatility range boundaries for VOC-IVOC and IVOC-SVOC occur between $\mathrm{C}_{12}-\mathrm{C}_{13}$ and $\mathrm{C}_{19}-\mathrm{C}_{20}$, respectively, for $n$-alkanes or compounds with equivalent volatilities. See Appendix B for calculations and Table S9.

et al., 2016; Weschler and Nazaroff, 2010). Our chemical analysis revealed IVOCs or SVOCs in 10 of the 17 products (Tables 1 and S1). Including the MSDS survey, we found total IVOC + SVOC compositions ranging from 0 to $95 \%$, with IVOCs or SVOCs present in $23 \%$ of cleaners, $20 \%$ of adhesives, $24 \%$ of paints, and $46 \%$ of sealants (Table 2). Aliphatic or aromatic IVOCs and SVOCs are frequently used in some types of pesticides and are sometimes replaced with biogenic oils (e.g., neem oil, fish oil) such that the bulk of the pesticides in our MSDS survey were comprised of $<1-$ $10 \%$ active compounds and a balance of undisclosed, "nonhazardous" ingredients.

The SPECIATE profiles and CARB emissions inventory include some estimates of unspeciated "low-vapor-pressure VOCs (LVP VOCs)" in consumer products that are defined as larger than 12 carbon atoms (or equivalent volatility), which is roughly consistent with the beginning of the IVOC range (California Air Resources Board, 2015b). While poorly constrained, nonaromatic IVOCs and SVOCs included in the inventory constitute $\sim 3 \%\left(6 \mathrm{tday}^{-1}\right)$ of total SoCAB emissions estimates in the CARB/SPECIATE case study, $90 \%$ of which are classified as unspeciated "LVP VOCs". Consumer product pesticides, general purpose cleaners, and targeted cleaners (e.g., laundry) are the largest sources of IVOC and SVOC contributions emitting 3.6, 1.0, and 0.4 tday $^{-1}$ of IVOCs and SVOCs, respectively. Consumer product pesticide emissions had the highest fraction of IVOCs and SVOCs $(29 \%)$.
While CARB's consumer products inventory includes IVOCs and SVOCs due to manufacturer reporting requirements, IVOCs and SVOCs are exempt from limits on VOC content except for multipurpose solvents and paint thinners, and there are known limitations in their coverage, especially of oxygenated species (California Air Resources Board, 2000, 2015b). We conclude that there are other anthropogenic sources of IVOCs and SVOCs that have not been considered due to their long emission timescales (i.e., daysyears; Fig. 4, Table S9; de Gouw et al., 2011; Weschler and Nazaroff, 2008). We present evidence for two such examples in this paper: IVOC- and SVOC-containing pesticides and asphalt-related products, materials, and processes, but other examples include the volatilization of IVOC and SVOC solvents, solutes, or solids (e.g., coatings, flame retardants) and materials that may degrade to form compounds with volatilities of $\mathrm{C}_{13-26} n$-alkanes (e.g., construction materials and coatings, including materials with petroleum distillates or residues, mineral oil, coal tar, or similar).

\section{Example 1: Emissions of IVOCs and SVOCs from pesticides}

We have several pieces of evidence demonstrating that pesticides (including herbicides, insecticides, and fungicides) contain IVOCs and SVOCs, but they also highlight the fact that they are poorly documented and regulated. We analyzed the chemical composition of three pesticides available as consumer products and they were comprised of 8,20 , and $95 \%$ IVOCs in the $\mathrm{C}_{14-17}$ range (Table 1, Fig. S3), with trace levels of larger compounds. Our MSDS survey (Table 2) was inconclusive for pesticides since the majority of consumer pesticides are not disclosed in MSDSs due to claims of proprietary mixtures, nonregulated components outside of the VOC range, and/or because they use naturally derived oils (e.g., neem oil). Studies have shown that such naturally derived oils are comprised of aliphatic and aromatic IVOC- and SVOC-range compounds (Isman, 2000; Kumar and Parmar, 1996). Our emissions inventory analysis shows that nonaromatic IVOCs and SVOCs are the largest inventoried source of IVOCs and SVOCs (Fig. 3), but the lack of data in MSDSs and VOC exemptions from regulations suggests that this is a lower estimate of actual emissions. To examine commercial and industrial products, we also analyzed the composition of three petroleum-based pesticides used in agriculture (Fig. S2), which are comprised of $\mathrm{C}_{16}-\mathrm{C}_{26}$ cyclic and acyclic alkanes mostly in the SVOC range that are applied as thin films via a sprayed water emulsion. These can partition to the gas phase over a range of emissions timescales (Fig. 4) and may impact urban (or downwind) areas in agricultural regions, with $18-29 \mathrm{Gg}$ applied year ${ }^{-1}$ in California. California-wide emissions from applied agricultural pesticides were nearly one-fifth of those from consumer products in 2015. However, the high IVOC and SVOC fraction in 
their composition and potential to emit over long timescales makes them an important consideration for air quality.

\section{Example 2: Emissions of IVOCs and SVOCs from asphalt-related products, materials, and processes}

We propose asphalt-related products, materials, and processes as important sources of IVOCs and SVOCs whose emissions are currently underestimated in inventories and require better quantification. Asphalt-containing materials are used in road paving and repair (and similar applications for roofing or other surfaces), are comprised of petroleumderived organic compounds that are predominantly nondistillable (i.e., nonvolatile) asphalts, and sometimes contain smaller amounts of VOCs, IVOCs, and/or SVOCs. They are used as sealers, coatings, and binders, mixed with aggregates to pave roads, and applied using either high application temperatures, water emulsions, and/or solvent.

The three paving- and roofing-related products we analyzed contained aliphatic and aromatic VOCs and IVOCs up to $\mathrm{C}_{18}$ present as solvents, with minor SVOC content (Fig. S3). Similarly, there were no IVOCs or SVOCs declared in the asphalt-containing products in our MSDS survey. Nonsolvent emissions during the hot storage, application, or resurfacing of these asphalts are caused by the degradation (i.e., fragmentation) of larger organic compounds from asphalts to form smaller compounds $\left(\mathrm{C}_{7}-\mathrm{C}_{30}\right)$, which include cyclic and acyclic alkanes, single-ring aromatics, PAHs (2ring, 3-ring, and 4-ring), and sulfur- or nitrogen-containing species (i.e., benzo- and dibenzo- thiophenes and furans), all of which were not present in the asphalt prior to heating (Cavallari et al., 2012b; Gasthauer et al., 2008; Kitto et al., 1997; Kriech et al., 2002; Lange et al., 2005; Lange and Stroup-Gardiner, 2007; The Asphalt Institute and European Bitumen Association, 2015). The total mass and composition of emissions is dependent on production methods, asphalt grade, and increases in magnitude and maximum molecular weight with storage and application temperatures (i.e., more SVOCs at high temperatures), which ranged $100-240^{\circ} \mathrm{C}$ or higher for roofing asphalts (Cavallari et al., 2012c; Gasthauer et al., 2008; Kitto et al., 1997; Kriech et al., 2002; Lange et al., 2005; Lange and Stroup-Gardiner, 2007; The Asphalt Institute \& European Bitumen Association, 2015).

Emissions of aromatic and aliphatic VOCs, IVOCs, and SVOCs from heated asphalt mixtures ("hot mix") during application have also been documented in occupational health studies on "asphalt fumes" (Cavallari et al., 2012a, b; Kriech et al., 2002; Lange et al., 2005; Lange and Stroup-Gardiner, 2007). Yet, current emissions inventories do not include emissions of VOCs, IVOCs, and SVOCs from the degradation of larger compounds during and after the application of asphalt mixes. Estimation methods focus solely on the evaporation of VOC solvents from "cutback asphalt", which is a mixture of asphalt and solvent included as an area source in the "solvent evaporation" category in Californian,
US, and EU inventories (California Air Resources Board and Sonoma Technology Inc., 2003; European Environment Agency, 2017; San Joaquin Valley Air Pollution Control District, 2008; US Environmental Protection Agency, 2014; US EPA, 1995). Road paving solvents are prohibited in nonattainment areas in California (Table S4), so emissions in the SoCAB case study are minor $\left(1 \mathrm{tday}^{-1}\right)$ and mostly smaller than $\mathrm{C}_{10}$ in the SPECIATE source profiles (Table S5; Cox et al., 2013).

Emission factors of degradation by-products do not exist, so we approximate lower limits on emission factors only for the period immediately during application using limited published data (see Sect. S3 in the Supplement), but longer timescale experiments are necessary. Calculated lower limits range from $100-2000 \mathrm{mg} \mathrm{kg}^{-1}$ of asphalt (not including aggregate) with a strong dependence on storage and application temperature. This is on the same order as motor vehicle emission factors and is greater than CARB's current emission factor for hot-mix asphalt (Hernandez, 2016; Gentner et al., 2017; San Joaquin Valley Air Pollution Control District, 2008). Yet, California's asphalt consumption of $1540000 \mathrm{t}$ liquid asphalt year ${ }^{-1}$ (Table S4) represents statewide IVOC and SVOC (+ VOC) emissions of $0.5-8 \mathrm{tday}^{-1}$ during application alone (The Asphalt Institute, 2015). This does not overwhelm current solvent VOC emissions from paving and roofing $\left(33 \mathrm{tday}^{-1}\right)$ but emphasizes the need for further research since the poorly constrained emissions largely include IVOCs and SVOCs emitted over long timescales and are known to have high SOA yields.

Asphalt-related emissions exemplify the stated need for life-cycle-focused approaches, with potential emissions across storage, transport, application, curing, weathering (e.g., degradation due to climate or UV radiation), and resurfacing. Their magnitude and composition will vary with production and handling methods, geologic source, and application type and location (especially climate). Emission pathways (from Sect. 2) include (1) the volatilization of application solvents and (3) the production and release of degradation by-products, while pathway (2) does not apply due to negligible off-gassing from extremely low-volatility undegraded asphalt constituents. The emission of asphalt degradation products may peak during construction-related activities primarily due to asphalt's exposure to high temperatures during its storage, application, or resurfacing. Still, seasonal highs in surface temperature (summer pavement maximums are $47-67^{\circ} \mathrm{C}$ and up to $70^{\circ} \mathrm{C}$ for roofs; Parker et al., 1997; Pomerantz et al., 2000) will likely affect the rate of internal transport and diffusion out of the "cured" asphalt layer, resulting in emissions extended over its lifetime (note: paving solvents are currently assumed to be emitted over several months; California Air Resources Board and Sonoma Technology Inc., 2003). 


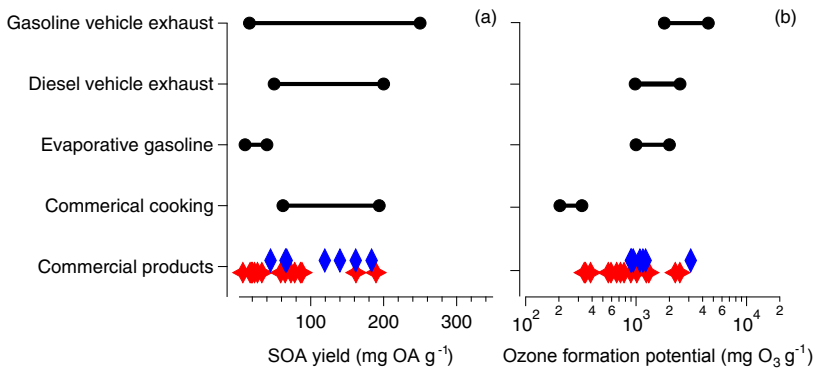

Figure 5. Comparison of (a) SOA yields and (b) ozone formation potential of five major sources. Blue markers represent average yields of the product- and process-related source categories in Fig. 3 and do not include "missing" emissions. The red markers show yields of sampled consumer products calculated from speciation obtained after GC-MS analysis. All are shown as a function of mass emitted, not product composition.

\subsection{Potential SOA and ozone formation of product- and process-related emissions compared to other major sources}

Products and processes emit a diverse array of organic compounds (Fig. 3). Some are of relatively low direct concern for human health (e.g., terpenoids), while others present issues as primary emissions, especially in indoor or concentrated workplace environments (e.g., aromatics, ethers, PAHs). Yet, most are reactive and will oxidize in outdoor or indoor environments to form oxidized VOCs with unknown but large potential health effects (Pöschl and Shiraiwa, 2015). This section focuses on their impacts on air quality via SOA or ozone formation. However, the health or environmental effects of the primary emissions should be especially considered in developing regions where primary VOC emissions are larger or for specific compound classes near sensitive natural environments. A comparison of the SOA yields and ozone formation potentials for major source categories (Fig. 5) demonstrates that product- and process-related emissions have SOA yields and ozone formation potentials that are on par with other major urban sources, such as motor vehicles, and are strongly dependent on composition.

\subsubsection{SOA formation potential}

The potential SOA from on-road gasoline vehicles in the greater Los Angeles region decreased by $\sim 65 \%$ between the years 1990 and 2015. By 2020, a further reduction by $25 \%$ is expected relative to the 2015 value of $3.3 \mathrm{tday}^{-1}$. These numbers for diesel vehicles are $75 \%$ and 1.3 tday $^{-1}$, respectively. If the emissions inventory is accurate, then the 2015 potential products- and process-related SOA in the So$\mathrm{CAB}$ is nearly equal to the SOA formation potential of onroad gasoline and diesel vehicles and is estimated to surpass them by 2020 with an increasing share of SoCAB's total anthropogenic emissions (Fig. 2b). While single-ring aromat- ics and PAHs constitute only $11 \%$ of the total product- and process-related emissions, they are responsible for $\sim 80 \%$ of the potential SOA from those sources in the region $(4 \%$ PAHs and $76 \%$ single-ring aromatics, largely toluene and xylenes). Existing emission inventories badly underestimate emissions of IVOCs and SVOCs and their contributions to SOA. They are shown to be responsible for $0.18 \%$ of product- and process-related SOA, but this excludes $87 \%$ of the total IVOC and SVOC emissions that are labeled as unspeciated "LVP VOCs" in the inventory and thus have no assigned SOA yield in calculations. Additionally, our calculations do not include "missing" emissions or their potential SOA. Anthropogenic terpenoids, including lemon oil, pine oil, orange oil, orange terpenes, D-limonene and $\alpha$-pinene, are responsible for $\sim 8 \%$ of the total product- and processrelated SOA.

It is important for future work to consider modifying factors for SOA (and ozone) formation chemistry. Relative VOC to $\mathrm{NO}_{x}$ ratios have been shown to affect the chemistry and production rates of SOA and ozone (Hallquist et al., 2009; Sillman, 1999; Zhao et al., 2017). For many cities outside Los Angeles, urban air quality develops against a backdrop of biogenic emissions of VOCs and IVOCs, which is critical to keep in mind as we pursue stricter emission targets for reactive organics. In some cases, such as in the Southeast US, biogenic emissions dominate over anthropogenic gas-phase organics, and emissions of $\mathrm{SO}_{2}$ and $\mathrm{NO}_{x}$ are large drivers of biogenic SOA formation (Xu et al., 2015). Similarly, gas-phase cooking emissions from food represent an additional uncertain source in urban air quality along with cooking POA, which has been more studied (Bruns et al., 2017; Hayes et al., 2013; Klein et al., 2016).

\subsubsection{Ozone formation potential}

Over the past several decades, potential ozone has been dominated by emissions from gasoline motor vehicles. Yet, in 2015 potential ozone from gasoline vehicles was only $30 \%$ greater than product- and process-related sources, and by 2020 product- and process-related emissions will surpass on-road motor vehicle contributions in the basin (Fig. 2c). Potential ozone from on-road diesel vehicles in 2015 was only $\sim 5 \%$ of that from product- and process-related sources. Contributions to potential ozone from product- and processrelated sources are $33 \%$ alcohols, $29 \%$ aromatics, and $12 \%$ alkanes (not including unspeciated "LVP VOCs"; Table S2). A recent ozone formation sensitivity analysis of solventrelated emissions speciation with 22 lumped species demonstrated that using input source profiles that are more detailed in terms of contributing compound classes would improve ozone model performance (von Schneidemesser et al., 2016). 


\subsubsection{Contributions from off-road combustion-related sources}

Off-road mobile sources are also significant sources of reactive precursors to SOA and ozone across a very diverse mix of sources and fuels (Cox et al., 2013; Gordon et al., 2013; May et al., 2014; Zhao et al., 2016). These sources have received greater regulatory attention in the past 20 years, and control policies (e.g., CARB, EPA) will add additional variance to the magnitude and composition of emissions (California Air Resources Board, 2017; Miller and Facanha, 2014; US EPA, 2017). Given the limited information on their diverse source profiles and thus their SOA and ozone yields (Gordon et al., 2013; McDonald et al., 2015), we constrain their uncertain contributions independent from on-road sources. Their fraction of VOC emissions in the SoCAB leveled off and started to decrease after 2005 (Fig. 2a), and in 2015 the ratio of on- to off-road emissions in the ARB inventory is $1.5: 1$ and $1: 2$ for gasoline- and diesel-powered engines, respectively, when including equipment, recreational vehicles, boats, trains, and aircraft that use either gasoline or diesel (Cox et al., 2013). Given similar ozone and SOA yields to on-road gasoline or diesel vehicles, the inclusion of off-road emissions could approximately increase potential SOA and ozone from gasoline- and diesel-related sources by 67 and $200 \%$, respectively, in 2015 (SoCAB). Yet, this is subject to uncertainty from the wide range of engines, fuels, and emission controls affecting the composition of emissions. These results are generally consistent with the relative source contributions of on- and off-road sources to total OA reported by McDonald et al. (2015) for 2010. The current outsize impact of off-road sources, despite using a relatively small amount of fuels, is due to the fact that emission factors are much higher, such as $2+$ orders of magnitude, for gasoline off-road compared to on-road sources (Gordon et al., 2013; McDonald et al., 2015; Zhao et al., 2016). The inclusion of off-road sources does not affect our conclusion that non-combustion sources and motor vehicles (on- and offroad) contribute similar amounts of potential SOA and ozone in our case study megacity around the 2015-2020 period, especially with a rapidly growing role for non-combustion sources as combustion emissions are further controlled. In all, this highlights the importance of continued assessment and regulation of off-road combustion-related sources as part of a holistic air quality management plan.

\subsection{Empirical ambient evidence for IVOC and SVOC emissions and their SOA contributions}

Ambient measurements (2010) of IVOCs and SVOCs in our case study city are consistent with our findings; they demonstrate that IVOCs are important contributors to SOA in the region and other urban areas, but major uncertainties persist regarding the sources of primary IVOC emissions (Hayes et al., 2015; Ma et al., 2016; Zhao et al., 2014). Recent model results estimate that $70-86 \%$ of urban SOA in Pasadena comes from the oxidation of primary IVOC and SVOC emissions (Ma et al., 2016). Zhao et al. (2014) state that unidentified non-vehicular sources contribute "substantially" to these emissions but no clear fraction is yet established. A major fraction of SOA cannot be explained without the inclusion of IVOCs or other unspeciated organics (Gentner et al., 2012, 2017; Hayes et al., 2015; Jathar et al., 2014; Zhao et al., 2014). Other results indicate that fossil-related sources contribute approximately half of OA and a majority of fresh, urban SOA in Los Angeles (Gentner et al., 2017; Hayes et al., 2013; Zotter et al., 2014). Yet, bottom-up estimates and topdown assessments of the SOA produced from gasoline and diesel vehicles (on- and off-road) cannot explain all of the observed fossil SOA in LA in 2010, which supports our conclusions and suggests the presence of other major sources of fossil-derived SOA precursors (Ensberg et al., 2014; Gentner et al., 2017; Ma et al., 2016; McDonald et al., 2015; Zhao et al., 2014).

\subsection{Isotopic carbon content and interpreting ambient isotopic data}

The isotopic carbon content (i.e., ${ }^{14} \mathrm{C}$ vs. ${ }^{13} \mathrm{C}$ vs. ${ }^{12} \mathrm{C}$ ) of organic aerosol has been used directly or in tandem with source apportionment of bulk aerosol data from an aerosol mass spectrometer to infer the fossil vs. nonfossil origin of carbonaceous aerosols and their SOA precursors at several locations (Ceburnis et al., 2011; Hayes et al., 2013; Zotter et al., 2014). We tested the potential effect of product- and processrelated emissions on the interpretation of isotopic measurements of ambient SOA, and our isotopic analysis of 12 products demonstrates that their VOC, IVOC, and SVOC emissions and thus SOA will be depleted in carbon-14 (Table 1): 8 of the 12 contained $97 \%$ or more fossil carbon, while the remaining 4 contained 57-81\% fossil carbon. Asphalt-related sealants, solvents (e.g., paint thinner, naphtha), and pesticides were found to have the highest fossil carbon content. This is consistent with the fact that petrochemical feedstocks derived from petroleum and other fossil fuels are used in the products, materials, and processes discussed throughout this work.

Studies in greater Los Angeles (Pasadena) report that fossil-fuel-driven emissions appear to contribute $68-74 \%$ of the observed afternoon increase in SOA formed from urban sources with the remaining $\sim 25 \%$ coming from nonfossil sources, principally regional biogenic and local cooking sources (Hayes et al., 2013, 2015; Zotter et al., 2014). The observed fossil SOA and its potential precursor sources have been analyzed across several studies with differing conclusions (Bahreini et al., 2012; Gentner et al., 2017; Hayes et al., 2013; Zotter et al., 2014). The studies agree that onroad diesel vehicles are a relatively minor contributor to fossil SOA (Bahreini et al., 2012; Hayes et al., 2013, 2015; Zotter et al., 2014) and along with other papers have pro- 
posed the importance of other, unconstrained anthropogenic sources (e.g., off-road sources; Ensberg et al., 2014; McDonald et al., 2015; Zhao et al., 2014). Other evidence suggests a fossil source other than on-road diesel since concentrations of IVOCs show only minor weekday vs. weekend variation with changes in diesel traffic (Zhao et al., 2014). Based on our results and the evidence in the literature, we conclude that fossil-derived urban SOA precursors are emitted from product- and process-related sources and are responsible for some of the fossil SOA observed in the SoCAB. The isotopic signature of products, materials, and processes is due to their petrochemical feedstocks, and this has led to their misattribution to combustion-related sources in the past.

\section{Conclusions and future research needs}

Using multiple bottom-up approaches, we demonstrate the growing importance of non-combustion emissions of gasphase organic compounds from anthropogenic sources. Yet, our understanding has been inhibited due to the chemical diversity of emissions across a myriad of source types, their fossil isotopic signatures, and in many cases their prolonged emission timescales, which occur over full life cycles and a broader range of emissions pathways than is typically considered. Emission timescales can extend over months or longer (Fig. 4) in the case of sources of IVOCs and SVOCs, emissions via transport through thick layers of materials and coatings, or the formation and emission of degradation byproducts. The implications of these prolonged timescales are a legacy of unreleased potential emissions built up or "banked" in the products and materials spread across urban areas.

It is critical to emphasize that these results do not justify deviating attention from or relaxing emission standards for combustion-related sources since they are still prominent factors in urban air quality in the developed and developing world and remain dominant contributors of carbon dioxide. For the foreseeable future in many locations, they remain the principal contributors of reactive organic precursors and other criteria pollutants, especially in near-source hotspots, such as roadways. Rather, we conclude that in order to support the coming decades of policy, modern air quality research needs to holistically consider the full portfolio of anthropogenic (and biogenic) sources that impact urban air quality. We highlight key research needs to support this objective.

\subsection{A broad perspective on nontraditional sources of reactive carbon}

This analysis highlights the importance and further consideration of VOC, IVOC, and SVOC sources that have not received sufficient attention to effectively support policy. With the successful control of "low-hanging fruit" whereby single source types dominated emissions, the control of a broader array of disparate sources becomes necessary. It is likely that there are other non-vehicular sources of reactive gas-phase organics in urban areas (e.g., food-derived cooking emissions) that need to be better included in inventories and models. Monitoring, studies, and inventories need to comprehensively include functionalized compound classes rather than just traditional classes.

\subsection{Validation of existing emissions inventories}

Our results based on existing emissions inventories are subject to uncertainties in their methodology. Given the results, further research is needed to review, evaluate, and validate both the emissions factors and source profiles in emissions inventories. A life cycle approach should include lifetime emissions over the three pathways stated in Sect. 2, which include solvent evaporation, solute volatilization, and emissions via the formation of degradation by-products. Such emissions will be seasonally dependent on factors such as air velocity, relative humidity, and temperature (Wolkoff, 1998). A large survey of products and materials with attention to national and/or regional differences is warranted to ensure that source profiles accurately represent product- and processrelated emissions, including "green-intentioned" options for comparison. Single-ring aromatics are a key example; the current CARB inventory using the SPECIATE source profiles reports large emissions of single-ring aromatics, $72 \%$ of which comes from paints. Yet, this is in contrast to our MSDS analysis of prevalent products, which observed little aromatic content in the surveyed US paints (Table 2).

\subsection{Inclusion of IVOCs and SVOCs in emissions inventories}

There is a clear need for more detailed emissions inventories of IVOCs and SVOCs from all sources. Further research should support the evaluation of the IVOC and SVOC exemption in strategic air quality management plans and composition reporting requirements in MSDSs and similar databases. More detailed chemical speciation with newer methods is required to accurately determine the SOA (and ozone) formation potential of unresolved IVOC and SVOC mixtures. In the process, attention should be paid to heterogeneity in products containing petroleum distillates and similar components, which are very broad and can result in an equally broad range of emissions.

The off-gassing of IVOCs and SVOCs (and VOCs) from materials was not experimentally tested in this study and is not included in inventories. Recent studies have shown that plastics, foams, and building materials off-gas IVOCs, SVOCs, and VOCs (e.g., aromatics, aliphatics, halocarbons, terpenes, organophosphates, and oxygenated species; Brodzik et al., 2014; Faber et al., 2013; Kemmlein et al., 2003; Toftum et al., 2008; Wensing et al., 2005). Similarly, 
the detailed lab and field characterization of asphalt-related emissions over long timescales is needed to constrain emission factors, source profiles, and the effect of modified asphalts.

Understanding the application method and environment is key to determining air emissions of IVOCs and SVOCs since some products may be used with water and disposed of into wastewater, which are described as "down-the-drain" factors. For example, a recent ozone modeling study modeled the fate of 23 oxygenated IVOCs and SVOCs (e.g., glycols, glycol ethers, esters, alcohols) present in cleaning and personal products that are used with water. They concluded that most of the compounds that go down the drain do not volatilize and are biodegraded at wastewater treatment plants, while $>90 \%$ of compounds that volatilize outdoors will react with $\mathrm{OH}$ and contribute to ozone formation (Shin et al., 2015).

\subsection{Quantifying outdoor transport of indoor emissions}

Similar to "down-the-drain" factors, we highlight the need for a similar factor to determine fractions of indoor emissions that are permanently lost to indoor sinks via chemical or physical deposition ("fraction lost to indoor sinks"). Similarly, models will need factors to account for the increase in characteristic emission timescales when potential emissions from products or materials remain indoors longer due to generally lower vertical transport coefficients and subsequent repartitioning to other surfaces prior to transport outdoors.

\subsection{Inter-location variability in the developed and developing world}

While we present annual trends for our case study megacity Los Angeles, a similar situation is evolving elsewhere in developed urban areas where emissions of anthropogenic organics are key drivers of SOA and ozone formation, especially in megacities. We expect substantial heterogeneity between locations in the composition of emissions from products, materials, and processes due to national and/or regional regulations governing formulation, climate, application specifics, and consumer preferences and options. In particular for this work, California's advanced regulatory program may have led to the phaseout of some components in US products. So globally the composition and magnitude of product- and process-related emissions may contain a much greater fraction of reactive species, such as single-ring aromatics. Top-down ambient studies and bottom-up studies for other locations are needed to confirm the importance of product- and process-related emissions, and air quality modeling studies should support these efforts. The situation in urban areas of developing regions and emerging economies is uncertain since they have motor vehicle emissions standards and technologies that may be much more advanced than the rest of their air quality management plans (Kodjak, 2015). In such locations, non-combustion sources may be important sources, but the combustion of fossil fuels or biomass for home heating, cooking, or agricultural waste disposal will play a larger role than in developed regions. In all locations, the magnitude of regional biogenic emissions and $\mathrm{SO}_{2} / \mathrm{NO}_{x}$ emissions will affect the impact of anthropogenic organics on SOA.

\subsection{Understudied oxidation pathways and products}

The oxidation pathways and products for many of the functionalized compound classes discussed in this work (e.g., Fig. 3) are largely understudied, with a lack of experimental or theoretical studies to constrain the generation of SOA, ozone, and oxidized gases. Such oxidation products and pathways are also particularly important in indoor environments, so research on their precursor emissions and subsequent oxidation is also important for indoor air chemistry.

Data availability. Most of the new data and the results produced for this paper are included in the Supplement, in addition to the publicly available emission inventories used in this paper (Cox et al., 2013; Carter, 2007; US Environmental Protection Agency, 2011, 2014). Additional details on product chemical speciation are available at https://www.gentner.yale.edu/khare-acp2018/ (last access: 19 April 2018). 


\section{Appendix A: Current and historical regulations and policy on non-combustion products and processes}

Emissions from consumer products and industrial processes received some attention in pre-2000 outdoor air quality research and policy, especially in the cases of toxic components, highly reactive volatile solvents that fueled rapid ozone production (e.g., alkenes), and stratospheric ozonedepleting chemicals. Emissions of a select few hazardous air pollutants (HAPs; e.g., benzene and vinyl chloride) were first broadly regulated under the US Clean Air Act (1970). Subsequent amendments through 1990 required the US Environmental Protection Agency (EPA) to regulate key sources of precursors to ozone production and emissions of 189 newly designated HAPs (now "air toxics"), some of which were used in products and processes (National Research Council, 2004). Less well-known is that the 1990 amendments also required the EPA to identify priorities and guidelines to mitigate emissions from consumer and commercial products (National Research Council, 2004). Several categories of paints and solvents were subsequently identified based on results from paint drying and chamber experiment studies conducted during the early 1970s through the late 1990s (Chang et al., 1997; Clausen et al., 1990, 1991, 1993; Hansen, 1974; Sparks et al., 1999; Sullivan, 1975), and regulations were established for half of the product categories, but actions were ultimately halted as these sources were not viewed as central to ozone or other criteria pollutant mitigation at the time (National Research Council, 2004). Despite large uncertainties about emissions and ambient contributions from products and processes, this strategy reflects the magnitude and impact of motor vehicle emissions in 1990 (Figs. 1-2), the keen focus on ozone production, and the lack of knowledge on SOA formation chemistry, IVOCs, and SVOCs.

US state- and/or air-basin-level regulations vary with region and attainment status. California's air quality policy and regulations have been the most inclusive and detailed with respect to emissions from consumer products and some industrial processes. The California Air Resources Board (CARB) started the Consumer Products Regulatory Program in 1991 and a similar Coatings Program to address outdoor and indoor air quality problems associated with their emissions by placing product-type-specific limits on VOC content and total reactivity limits (i.e., ozone potential) specifically for aerosol coatings (California Air Resources Board, 2015b). CARB is also required to maintain statewide and countyand basin-level emissions inventories for 72 source categories available for 1975 to 2020. Within these categories, the product- and process-related sources include consumer products, architectural coatings, pesticides, cleaning and surface coatings, and asphalt paving and roofing. Chemically speciated emissions profiles for sources within these categories are in the US EPA's SPECIATE repository, some of which are used by the European Union (EU; Pernigotti et al., 2016). In the 2015 California code of regulations re- port, CARB further updated regulations focusing on VOC emissions from antiperspirants and deodorants, hair sprays, other consumer products (both aerosol and nonaerosol), and aerosol coating products (California Air Resources Board, 2015a).

The Economic Commission of Europe employs marketbased mechanisms to reduce regional emissions of VOCs. The National Emissions Ceilings directive sets countryspecific reduction targets on organic gas emissions ranging from 10 up to $60 \%$ from 2010 to 2020 (European Environment Agency, 2010). The EU has two relevant policy directives: the "VOC Solvents Emissions Directive" to limit industrial VOC emissions resulting from processes such as printing, surface cleaning, vehicular coating, and dry cleaning and the "Paints Directive" to reduce VOC content in paints and varnishes (European Commission, 2014). In China, in addition to restrictions on criteria pollutants including both $\mathrm{PM}_{10}$ and $\mathrm{PM}_{2.5}$, the Chinese Air Pollution Control Action Plan 2013 also limits VOC emissions from paints, adhesives, and the petrochemical industry and promotes the use of low-volatility water-based paints (Ministry of Environmental Protection, 2012).

\section{Appendix B: Calculating characteristic timescales for emissions from surface layers}

The timescale for emission is defined by the simple relation

$\tau_{\text {emission }}=\frac{M_{\text {applied }}}{R_{\text {emission }}}$.

The mass applied ( $\left.M_{\text {applied }}\right)$ and rate of emission $\left(R_{\text {emission }}\right)$ are defined as in Weschler and Nazaroff (2008); as a function of emission velocity, $\left(v_{\mathrm{e}}\right)$ refers to the airborne mass transfer from the surface of the applied layer to the freestream air, which is the rate-limiting step compared to diffusion within the thin layer (Weschler and Nazaroff, 2008). The gas-phase saturation concentration immediately above the surface $\left(C_{\mathrm{sat}}\right)$ is determined by molecular structure, $C_{\mathrm{O}}$ is the concentration of a compound in the layer, $A$ is the exposed surface, and $d$ is the depth of the layer.

$R_{\mathrm{emission}}=v_{\mathrm{e}} A C_{\mathrm{sat}}$

$M_{\text {applied }}=C_{\mathrm{O}} A d$

By plugging Eqs. (B2)-(B3) into Eq. (B1) and substituting in the partitioning coefficient between octanol and air $\left(K_{\mathrm{OA}}\right)$, one gets Eqs. (B4) and (B6): octanol is chosen as the proxy for the mixed organic layer that is applied. $K_{\mathrm{OA}}$ is available for a wide range of species and is consistent with previous modeling of SVOC partitioning from surfaces (Weschler and Nazaroff, 2008).

$\tau_{\text {emission }}=\frac{C_{\mathrm{O}} A d}{v_{\mathrm{e}} \mathrm{A} C_{\mathrm{sat}}}=\frac{C_{\mathrm{O}} d}{v_{\mathrm{e}} C_{\mathrm{sat}}}$ 
since

$K_{\mathrm{OA}}=\frac{C_{\mathrm{o}}}{C_{\mathrm{sat}}}$,

$\tau_{\mathrm{emission}}=\frac{K_{\mathrm{OA}} d}{v_{\mathrm{e}}}$,

where $v_{\mathrm{e}}$ is a function of aerodynamic and boundary layer resistances $\left(r_{\mathrm{a}}\right.$ and $\left.r_{\mathrm{b}}\right)$ and can vary dramatically across indoor and outdoor environments. Given the diversity of compositions, applications, and environments in which products and materials will be applied, constraining $v_{\mathrm{e}}$ is uncertain and highly variable. Calculations in Table S9 and Fig. 4 are shown for a range of $v_{\mathrm{e}}$ values from 10 to $50 \mathrm{mh}^{-1}$, which covers a mix of moderately stable to neutral meteorological conditions. Higher values regularly occur for transport in and out of some plant canopies. Urban values are strongly dependent on the urban landscape and regional meteorology; vertical transport velocities in built-up urban areas like Paris range $5-20 \mathrm{~m} \mathrm{~h}^{-1}$ (Cherin et al., 2015). Indoor values can decrease to $<5 \mathrm{mh}^{-1}$ due to lower friction velocities, which is still fast enough for the emissions and chemistry that drive indoor air quality (Weschler and Nazaroff, 2008). $10-50 \mathrm{mh}^{-1}$ was chosen as a daytime range, but we acknowledge that slower vertical velocities and thus longer persistence on surfaces (i.e., lifetimes) may exist for some locations, especially indoors. Equations (B7)-(B11) to calculate $v_{\mathrm{e}}, r_{\mathrm{a}}$, and $r_{\mathrm{b}}$ are reproduced below for location- and condition-specific analyses. $v_{\mathrm{e}}=\frac{1}{r_{\mathrm{a}}+r_{\mathrm{b}}}$

$r_{\mathrm{a}}=\frac{1}{\kappa u^{*}} \ln \left(\frac{z_{\mathrm{r}}}{z_{0}}\right)$

$r_{\mathrm{b}}=\frac{5 S c^{2 / 3}}{u^{*}}$

$S c=v / D$

$u^{*}=\kappa U_{\mathrm{r}}\left[\ln \left(\frac{z_{\mathrm{r}}}{z_{0}}\right)\right]^{-1}$

Here, $u^{*}$ is friction velocity, $z_{0}$ is roughness length, $z_{\mathrm{r}}$ is reference height, $U_{\mathrm{r}}$ is reference velocity, $\kappa$ is the von Karman constant, $S c$ is the Schmidt number, $v$ is kinematic viscosity, and $D$ is gas diffusivity. Depending on the relative impact of $r_{\mathrm{a}}$ vs. $r_{\mathrm{b}}$, decreases in diffusivity with larger molecules may affect transport. 


\section{Information about the Supplement}

Please see the Supplement for additional details on relevant regulations, methods, Tables S1-S9, and Figs. S1-S5.

Competing interests. The authors declare that they have no conflict of interest.

Acknowledgements. We thank Jonathan Williams (Max Planck Institute for Chemistry) and Madeleine Strum (and the EPA SPECIATE group) for helpful feedback and the reviewers whose comments helped improve this paper. Drew R. Gentner acknowledges support from the US Environmental Protection Agency (no. RD83587101), yet the publication has not been reviewed by the EPA and it does not endorse any views, products, or services in this work. We would also like to thank John Karlik (U. California Cooperative Extension Kern County) for agricultural pesticide samples and Emily Barnes (Yale) for help with their preliminary analysis.

Edited by: Paul Monks

Reviewed by: two anonymous referees

\section{References}

Algrim, L. B. and Ziemann, P. J.: Effect of the Keto Group on Yields and Composition of Organic Aerosol Formed from OH RadicalInitiated Reactions of Ketones in the Presence of $\mathrm{NO}_{x}$, J. Phys. Chem. A, 6978-6989, https://doi.org/10.1021/acs.jpca.6b05839, 2016.

Bahreini, R., Middlebrook, A. M., de Gouw, J. A., Warneke, C., Trainer, M., Brock, C. A., Stark, H., Brown, S. S., Dube, W. P., Gilman, J. B., Hall, K., Holloway, J. S., Kuster, W. C., Perring, a. E., Prevot, A. S. H., Schwarz, J. P., Spackman, J. R., Szidat, S., Wagner, N. L., Weber, R. J., Zotter, P., and Parrish, D. D.: Gasoline emissions dominate over diesel in formation of secondary organic aerosol mass, Geophys. Res. Lett., 39, L06805, https://doi.org/10.1029/2011GL050718, 2012.

Batterman, S. A., Chernyak, S., Jia, C., Godwin, C., and Charles, S.: Concentrations and emissions of polybrominated diphenyl ethers from U.S. houses and garages., Environ. Sci. Technol., 43, 2693 2700, https://doi.org/10.1021/ES8029957, 2009.

Bishop, G. A. and Stedman, D. H.: A Decade of On-road Emissions Measurements, Environ. Sci. Technol., 42, 1651-1656, https://doi.org/10.1021/es702413b, 2008.

Brodzik, K., Faber, J., Łomankiewicz, D., and Gołda-Kopek, A.: In-vehicle VOCs composition of unconditioned, newly produced cars, J. Environ. Sci., 26, 1052-1061, https://doi.org/10.1016/S1001-0742(13)60459-3, 2014.

Bruns, E. A., Slowik, J. G., El Haddad, I., Kilic, D., Klein, F., Dommen, J., Temime-Roussel, B., Marchand, N., Baltensperger, U., and Prévôt, A. S. H.: Characterization of gas-phase organics using proton transfer reaction time-of-flight mass spectrometry: fresh and aged residential wood combustion emissions, Atmos. Chem. Phys., 17, 705-720, https://doi.org/10.5194/acp-17-7052017, 2017.
California Air Resources Board: Aerosol Coatings \& Consumer Products Methodology, Sect. 6.1 Consum. Prod., available at: https://www.arb.ca.gov/ei/areasrc/arbsolevapaercoatcp.htm (last access: 24 February 2017), 2000.

California Air Resources Board: EMFAC2014 Web Database (v1.0.7), available at: http://www.arb.ca.gov/emfac/2014/ (last access: 13 April 2018), 2014.

California Air Resources Board: Consumer Products Program Regulations, available at: https://www.arb.ca.gov/consprod/regs/ regs.htm (last access: 23 February 2017), 2015a.

California Air Resources Board: Regulation for reducing emissions from consumer products, Sacramento, available at: https://www. arb.ca.gov/consprod/regs/2015/regs-all_final_1-22-15.pdf (last access: 13 April 2018), 2015b.

California Air Resources Board: Off-Road Mobile Sources Emission Reduction Program, available at: https://www.arb.ca.gov/ msprog/offroad/offroad.htm, last access: 15 August 2017.

California Air Resources Board and Sonoma Technology Inc.: Attachment C: Asphalt Paving and Roofing, CCOS II Emiss. Invent. Proj., 2003.

Carter, W. P. L.: SAPRC Atmospheric Chemical Mechanisms and VOC Reactivity Scales, available at: http://www.cert.ucr.edu/ $\sim$ carter/SAPRC/ (last access: 13 April 2018), 2007.

Caserini, S., Fraccaroli, A., Monguzzi, A. M., Moretti, M., Giudici, A., and Gurrieri, G. L.: A detailed Emission Inventory for air quality planning at local scale: the Lombardy (Italy) experience, in: 13th International Emission Inventory Conference "Working for Clean Air in Clearwater," Clearwater, FL, 8-10 June 2004, available at: https://www3.epa.gov/ttn/chief/conference/ ei13/poster/caserini.pdf, 2004.

Cavallari, J. M., Osborn, L. V., Snawder, J. E., Kriech, A. J., Olsen, L. D., Herrick, R. F., and Mcclean, M. D.: Predictors of Airborne Exposures to Polycyclic Aromatic Compounds and Total Organic Matter among Hot-Mix Asphalt Paving Workers and Influence of Work Conditions and Practices, Ann. Occup. Hyg., 56, 138-147, https://doi.org/10.1093/annhyg/mer088, 2012a.

Cavallari, J. M., Zwack, L. M., Lange, C. R., Herrick, R. F., and Mcclean, M. D.: Temperature-Dependent Emission Concentrations of Polycyclic Aromatic Hydrocarbons in Paving and Built-Up Roofing Asphalts, Ann. Occup. Hyg., 56, 148-160, https://doi.org/10.1093/annhyg/mer107, 2012b.

Cavallari, J. M., Zwack, L. M., Lange, C. R., Herrick, R. F., and Mcclean, M. D.: Temperature-Dependent Emission Concentrations of Polycyclic Aromatic Hydrocarbons in Paving and Built-Up Roofing Asphalts, Ann. Occup. Hyg., 56, 148-160, https://doi.org/10.1093/annhyg/mer107, 2012c.

Ceburnis, D., Garbaras, A., Szidat, S., Rinaldi, M., Fahrni, S., Perron, N., Wacker, L., Leinert, S., Remeikis, V., Facchini, M. C., Prevot, A. S. H., Jennings, S. G., Ramonet, M., and O'Dowd, C. D.: Quantification of the carbonaceous matter origin in submicron marine aerosol by ${ }^{13} \mathrm{C}$ and ${ }^{14} \mathrm{C}$ isotope analysis, Atmos. Chem. Phys., 11, 8593-8606, https://doi.org/10.5194/acp11-8593-2011, 2011.

Censullo, A. C., Jones, D. R., and Wills, M. T.: Investigation of Low Reactivity Solvents- Final Report to California Air Resources Board Research Division on Contract No. 98-310, 2002.

Chacon-Madrid, H. J., Presto, A. A., and Donahue, N. M.: Functionalization vs. fragmentation: n-aldehyde oxidation mechanisms 
and secondary organic aerosol formation, Phys. Chem. Chem. Phys., 12, 13975, https://doi.org/10.1039/c0cp00200c, 2010.

Chan, A. W. H., Chan, M. N., Surratt, J. D., Chhabra, P. S., Loza, C. L., Crounse, J. D., Yee, L. D., Flagan, R. C., Wennberg, P. O., and Seinfeld, J. H.: Role of aldehyde chemistry and $\mathrm{NO}_{x}$ concentrations in secondary organic aerosol formation, Atmos. Chem. Phys., 10, 7169-7188, https://doi.org/10.5194/acp10-7169-2010, 2010.

Chang, J. C. S., Tichenor, B. A., Guo, Z., and Krebs, K. A.: Substrate Effects on VOC Emissions from a Latex Paint, Indoor Air, 7, 241-247, https://doi.org/10.1111/j.1600-0668.1997.00003.x, 1997.

Chang, Y.-M., Hu, W.-H., Fang, W.-B., Chen, S.-S., Chang, C.-T., and Ching, H.-W.: A study on dynamic volatile organic compound emission characterization of water-based paints, J. Air Waste Manag. Assoc., 61, 35-45, 2011.

Chen, C. H., Li, L., Huang, C., Chen, Z., Wang, H. L., Huang, H. Y., and Al, E.: Study on the air pollution control countermeasures for 2010 EXPO, Shanghai Academy of Environmental Sciences, Shanghai, China, 2009.

Cherin, N., Roustan, Y., Musson-Genon, L., and Seigneur, C.: Modelling atmospheric dry deposition in urban areas using an urban canopy approach, Geosci. Model Dev., 8, 893-910, https://doi.org/10.5194/gmd-8-893-2015, 2015.

Clausen, P. A., Wolkoff, P., and Nielsen, P. A.: Long-term environmental chamber tests of waterborne paints (in Danish) (SBI report 207), Horsholm, Denmark, 1990.

Clausen, P. A., Wolkoff, P., Hoist, E., and Nielsen, P. A.: Longterm Emission of Volatile Organic Compounds from Waterborne Paints - Methods of Comparison, Indoor Air, 1, 562-576, https://doi.org/10.1111/j.1600-0668.1991.00019.x, 1991.

Clausen, P. A., Laursen, B., Wolkoff, P., Rasmusen, E., and Nielsen, P. A.: Emission of Volatile Organic Compounds from a Vinyl Floor Covering, in: Modeling of Indoor Air Quality and Exposure, edited by: Nagda, N. L., 3-11, ASTM International, Philadelphia, 1993.

Clausen, P. A., Hansen, V., Gunnarsen, L., Afshari, A., and Wolkoff, P.: Emission of di-2-ethylhexyl phthalate from PVC flooring into air and uptake in dust: emission and sorption experiments in FLEC and CLIMPAQ, Environ. Sci. Technol., 38, 2531-2537, 2004.

Cohen, A. J., Ross Anderson, H., Ostro, B., Pandey, K. D., Krzyzanowski, M., Künzli, N., Gutschmidt, K., Pope, A., Romieu, I., Samet, J. M., and others: The global burden of disease due to outdoor air pollution, J. Toxicol. Environ. Heal. Part A, 68, 1301-1307, 2005.

Cox, P., Delao, A., and Komorniczak, A.: The California Almanac of Emissions and Air Quality - 2013 Edition, California Air Resources Board, Sacramento CA USA, 2013.

Daumit, K. E., Carrasquillo, A. J., Sugrue, R. A., and Kroll, J. H.: Effects of Condensed-Phase Oxidants on Secondary Organic Aerosol Formation, J. Phys. Chem. A, 120, 1386-1394, https://doi.org/10.1021/acs.jpca.5b06160, 2016.

de Gouw, J. A., Middlebrook, A. M., Warneke, C., Ahmadov, R., Atlas, E. L., Bahreini, R., Blake, D. R., Brock, C. A., Brioude, J., Fahey, D. W., Fehsenfeld, F. C., Holloway, J. S., Le Henaff, M., Lueb, R. A., McKeen, S. A., Meagher, J. F., Murphy, D. M., Paris, C., Parrish, D. D., Perring, A. E., Pollack, I. B., Ravishankara, A. R., Robinson, A. L., Ryer- son, T. B., Schwarz, J. P., Spackman, J. R., Srinivasan, A., and Watts, L. A.: Organic Aerosol Formation Downwind from the Deepwater Horizon Oil Spill, Science, 331, 1295-1299, https://doi.org/10.1126/science.1200320, 2011.

de Gouw, J. A., Gilman, J. B., Borbon, A., Warneke, C., Kuster, W. C., Goldan, P. D., Holloway, J. S., Peischl, J., Ryerson, T. B., Parrish, D. D., and Others: Increasing atmospheric burden of ethanol in the United States, Geophys. Res. Lett., 39, L15803, https://doi.org/10.1029/2012GL052109, 2012.

Deguillaume, L., Beekmann, M., and Derognat, C.: Uncertainty evaluation of ozone production and its sensitivity to emission changes over the Ile-de-France region during summer periods, J. Geophys. Res., 113, D02304, https://doi.org/10.1029/2007JD009081, 2008.

Destaillats, H., Lunden, M. M., Singer, B. C., Coleman, B. K., Hodgson, A. T., Weschler, C. J., and Nazaroff, W. W.: Indoor Secondary Pollutants from Household Product Emissions in the Presence of Ozone: A Bench-Scale Chamber Study, Environ. Sci. Technol., 40, 4421-4428, https://doi.org/10.1021/ES052198Z, 2006.

Dzepina, K., Volkamer, R. M., Madronich, S., Tulet, P., Ulbrich, I. M., Zhang, Q., Cappa, C. D., Ziemann, P. J., and Jimenez, J. L.: Evaluation of recently-proposed secondary organic aerosol models for a case study in Mexico City, Atmos. Chem. Phys., 9, 5681-5709, https://doi.org/10.5194/acp-9-5681-2009, 2009.

Ensberg, J. J., Hayes, P. L., Jimenez, J. L., Gilman, J. B., Kuster, W. C., de Gouw, J. A., Holloway, J. S., Gordon, T. D., Jathar, S., Robinson, A. L., and Seinfeld, J. H.: Emission factor ratios, SOA mass yields, and the impact of vehicular emissions on SOA formation, Atmos. Chem. Phys., 14, 2383-2397, https://doi.org/10.5194/acp-14-2383-2014, 2014.

European Commission: VOC Solvents Emissions Directive - Environment - European Commission, available at: http://ec.europa. eu/environment/archives/air/stationary/solvents/legislation.htm (last access: 17 February 2017), 2014.

European Environment Agency: Emissions of ozone precursors, Copenhagen, 2010.

European Environment Agency: European Union emission inventory report 1990-2015 under the UNECE Convention on Long-range Transboundary Air Pollution (LRTAP) - European Environment Agency, EEA Report, No. 9/2017 available at: https://www.eea.europa.eu/publications/ annual-eu-emissions-inventory-report (last access: 20 February 2018), 2017.

Faber, J., Brodzik, K., Gołda-Kopek, A., and Łomankiewicz, D.: Benzene, toluene and xylenes levels in new and used vehicles of the same model, J. Environ. Sci., 25, 2324-2330, https://doi.org/10.1016/S1001-0742(12)60333-7, 2013.

Fortin, T. J., Howard, B. J., Parrish, D. D., Goldan, P. D., Kuster, W. C., Atlas, E. L. and Harley, R. A.: Temporal changes in U.S. benzene emissions inferred from atmospheric measurements, Environ. Sci. Technol., 39, 1403-1408, https://doi.org/10.1021/ES049316N, 2005.

Gasthauer, E., Mazé, M., Marchand, J. P., and Amouroux, J.: Characterization of asphalt fume composition by GC/MS and effect of temperature, Fuel, 87, 1428-1434, https://doi.org/10.1016/j.fuel.2007.06.025, 2008.

GEIA: Emissions of atmospheric Compounds \& Compilation of Ancillary Data (ECCAD) - The Global Emissions InitiA- 
tive (GEIA) Database, available at: http://eccad.sedoo.fr/eccad_ extract_interface/JSF/page_login.jsf, ast access: 24 February 2017.

Gentner, D. R., Isaacman, G., Worton, D. R., Chan, A. W. H., Dallmann, T. R., Davis, L., Liu, S., Day, D. A., Russell, L. M., Wilson, K. R., Weber, R., Guha, A., Harley, R. A., and Goldstein, A. H.: Elucidating secondary organic aerosol from diesel and gasoline vehicles through detailed characterization of organic carbon emissions, P. Natl. Acad. Sci. USA, 109, 18318-18323, https://doi.org/10.1073/pnas.1212272109, 2012.

Gentner, D. R., Worton, D. R., Isaacman, G., Davis, L. C., Dallmann, T. R., Wood, E. C., Herndon, S. C., Goldstein, A. H., and Harley, R. A.: Chemical composition of gas-phase organic carbon emissions from motor vehicles and implications for ozone production, Environ. Sci. Technol., 47, 11837-11848, https://doi.org/10.1021/es401470e, 2013.

Gentner, D. R., Jathar, S. H., Gordon, T. D., Bahreini, R., Day, D. A., El Haddad, I., Hayes, P. L., Pieber, S. M., Platt, S. M., de Gouw, J., Goldstein, A. H., Harley, R. A., Jimenez, J. L., Prévôt, A. S. H., and Robinson, A. L.: Review of Urban Secondary Organic Aerosol Formation from Gasoline and Diesel Motor Vehicle Emissions, Environ. Sci. Technol., 51, 10741093, https://doi.org/10.1021/acs.est.6b04509, 2017.

Giannouli, M., Kalognomou, E.-A., Mellios, G., Moussiopoulos, N., Samaras, Z., and Fiala, J.: Impact of European emission control strategies on urban and local air quality, Atmos. Environ., 45, 4753-4762, https://doi.org/10.1016/j.atmosenv.2010.03.016, 2011.

Gold, M. D., Blum, A., and Ames, B. N.: Another flame retardant, tris-(1,3-dichloro-2-propyl)-phosphate, and its expected metabolites are mutagens., Science, 200, 785-787, 1978.

Goldstein, A. H. and Galbally, I. E.: Known and Unexplored Organic Constituents in the Earth's Atmosphere, Environ. Sci. Technol., 41, 1514-1521, https://doi.org/10.1021/es072476p, 2007.

Gordon, T. D., Tkacik, D. S., Presto, A. A., Zhang, M., Jathar, S. H., Nguyen, N. T., Massetti, J., Truong, T., Cicero-Fernandez, P., Maddox, C., Rieger, P., Chattopadhyay, S., Maldonado, H., Maricq, M. M., and Robinson, A. L.: Primary gas- and particlephase emissions and secondary organic aerosol production from gasoline and diesel off-road engines, Environ. Sci. Technol., 47, 14137-14146, https://doi.org/10.1021/es403556e, 2013.

Hallquist, M., Wenger, J. C., Baltensperger, U., Rudich, Y., Simpson, D., Claeys, M., Dommen, J., Donahue, N. M., George, C., Goldstein, A. H., Hamilton, J. F., Herrmann, H., Hoffmann, T., Iinuma, Y., Jang, M., Jenkin, M. E., Jimenez, J. L., Kiendler-Scharr, A., Maenhaut, W., McFiggans, G., Mentel, Th. F., Monod, A., Prévôt, A. S. H., Seinfeld, J. H., Surratt, J. D., Szmigielski, R., and Wildt, J.: The formation, properties and impact of secondary organic aerosol: current and emerging issues, Atmos. Chem. Phys., 9, 5155-5236, https://doi.org/10.5194/acp9-5155-2009, 2009.

Hansen, C. M.: The Air Drying of Latex Coatings, Ind. Eng. Chem. Prod. Res. Dev., 13, 150-152, https://doi.org/10.1021/i360050a015, 1974.

Hao, J., Wang, L., Shen, M., Li, L., and Hu, J.: Air quality impacts of power plant emissions in Beijing, Environ. Pollut., 147, 401408, https://doi.org/10.1016/j.envpol.2006.06.013, 2007.
Hayes, P. L., Ortega, A. M., Cubison, M. J., Froyd, K. D., Zhao, Y., Cliff, S. S., Hu, W. W., Toohey, D. W., Flynn, J. H., Lefer, B. L., Grossberg, N., Alvarez, S., Rappenglück, B., Taylor, J. W., Allan, J. D., Holloway, J. S., Gilman, J. B., Kuster, W. C., de Gouw, J. A., Massoli, P., Zhang, X., Liu, J., Weber, R. J., Corrigan, A. L., Russell, L. M., Isaacman, G., Worton, D. R., Kreisberg, N. M., Goldstein, A. H., Thalman, R., Waxman, E. M., Volkamer, R., Lin, Y. H., Surratt, J. D., Kleindienst, T. E., Offenberg, J. H., Dusanter, S., Griffith, S., Stevens, P. S., Brioude, J., Angevine, W. M., and Jimenez, J. L.: Organic aerosol composition and sources in Pasadena, California, during the 2010 CalNex campaign, J. Geophys. Res.-Atmos., 118, 9233-9257, https://doi.org/10.1002/jgrd.50530, 2013.

Hayes, P. L., Carlton, A. G., Baker, K. R., Ahmadov, R., Washenfelder, R. A., Alvarez, S., Rappenglück, B., Gilman, J. B., Kuster, W. C., de Gouw, J. A., Zotter, P., Prévôt, A. S. H., Szidat, S., Kleindienst, T. E., Offenberg, J. H., Ma, P. K., and Jimenez, J. L.: Modeling the formation and aging of secondary organic aerosols in Los Angeles during CalNex 2010, Atmos. Chem. Phys., 15, 5773-5801, https://doi.org/10.5194/acp-15-5773-2015, 2015.

Hernandez, I.: 2012 Area Source Emissions Inventory Methodology; 540-Asphalt Paving, Imperial County Air Pollution Control District, California, 2016.

Isman, M. B.: Plant essential oils for pest and disease management, Crop Prot., 19, 603-608, https://doi.org/10.1016/S02612194(00)00079-X, 2000.

Jathar, S. H., Gordon, T. D., Hennigan, C. J., Pye, H. O. T., Pouliot, G., Adams, P. J., Donahue, N. M., and Robinson, A. L.: Unspeciated organic emissions from combustion sources and their influence on the secondary organic aerosol budget in the United States, P. Natl. Acad. Sci. USA, 111, 10473-10478, https://doi.org/10.1073/pnas.1323740111, 2014.

Jerrett, M., Burnett, R. T., Pope, C. A., Ito, K., Thurston, G., Krewski, D., Shi, Y., Calle, E., and Thun, M.: Long-term ozone exposure and mortality, N. Engl. J. Med., 360, 1085-1095, 2009.

Jia, L. and Xu, Y.: Effects of Relative Humidity on Ozone and Secondary Organic Aerosol Formation from the Photooxidation of Benzene and Ethylbenzene, Aerosol Sci. Technol., 48, 1-12, https://doi.org/10.1080/02786826.2013.847269, 2014.

Kemmlein, S., Hahn, O., and Jann, O.: Emissions of organophosphate and brominated flame retardants from selected consumer products and building materials, Atmos. Environ., 37, 54855493, https://doi.org/10.1016/j.atmosenv.2003.09.025, 2003.

Kirchstetter, T. W., Singer, B. C., Harley, R. A., Kendall, G. R., and Traverse, M.: Impact of California Reformulated Gasoline on Motor Vehicle Emissions. 1. Mass Emission Rates, Environ. Sci. Technol., 33, 318-328, https://doi.org/10.1021/es9803714, 1999.

Kitto, A. M., Pirbazari, M., Badriyha, B. N., Ravindran, V., Tyner, R., and Synolakis, C. E.: Emissions of Volatile and Semi-Volatile Organic Compounds and Particulate Matter from Hot Asphalts, Environ. Technol., 18, 121-138, https://doi.org/10.1080/09593331808616520, 1997.

Klein, F., Platt, S. M., Farren, N. J., Detournay, A., Bruns, E. A., Bozzetti, C., Daellenbach, K. R., Kilic, D., Kumar, N. K., Pieber, S. M., Slowik, J. G., Temime-Roussel, B., Marchand, N., Hamilton, J. F., Baltensperger, U., Prévôt, A. S. H., and El Haddad, I.: Characterization of Gas-Phase Organics Using Proton Transfer Reaction Time-of-Flight Mass Spectrome- 
try: Cooking Emissions, Environ. Sci. Technol., 50, 1243-1250, https://doi.org/10.1021/acs.est.5b04618, 2016.

Knudsen, H. N., Kjaer, U. D., Nielsen, P. A., and Wolkoff, P.: Sensory and chemical characterization of VOC emissions from building products: impact of concentration and air velocity, Atmos. Environ., 33, 1217-1230, https://doi.org/10.1016/S13522310(98)00278-7, 1999.

Kodjak, D.: Policies to Reduce Fuel Consumption, Air Pollution, and Carbon Emissions from Vehicles in G20 Nations, available at: http://www.theicct.org/sites/default/files/publications/ICCT_ G20-briefing-paper_Jun2015_updated.pdf (last access: 13 April 2018), 2015.

Kriech, A. J., Kurek, J. T., Wissel, H. L., Osborn, L. V., and Blackburn, G. R.: Evaluation of Worker Exposure to Asphalt Paving Fumes Using Traditional and Nontraditional Techniques, AIHA J., 63, 628-635, https://doi.org/10.1080/15428110208984749, 2002.

Kroll, J. H. and Seinfeld, J. H.: Chemistry of secondary organic aerosol: Formation and evolution of low-volatility organics in the atmosphere, Atmos. Environ., 42, 3593-3624, https://doi.org/10.1016/j.atmosenv.2008.01.003, 2008.

Kumar, J. and Parmar, B. S.: Physicochemical and Chemical Variation in Neem Oils and Some Bioactivity Leads against Spodoptera litura F, J. Agric. Food Chem., 44, 2137-2143, 19996.

Kwok, E. and Atkinson, R.: Estimation of hydroxyl radical reaction rate constants for gas-phase organic compounds using a structure-reactivity relationship: An update, Atmos. Environ., 29, 1685-1695, https://doi.org/10.1016/1352-2310(95)00069-B, 1995.

Lange, C. R. and Stroup-Gardiner, M.: TemperatureDependent Chemical-Specific Emission Rates of Aromatics and Polyaromatic Hydrocarbons (PAHs) in Bitumen Fume, J. Occup. Environ. Hyg., 4, 72-76, https://doi.org/10.1080/15459620701385279, 2007.

Lange, C., Stroup-Gardiner, M., and Cr, L.: Quantification of Potentially Odorous Volatile Organic Compounds from Asphalt Binders Using Head-Space Gas Chromatography, J. Test. Eval., 33, 1-9, https://doi.org/10.1520/JTE11800, 2005.

Lewis, R. G.: Pesticides, in: Indoor Air Quality Handbook, edited by: Spengler, J. D., McCarthy, J. F., and Samet, J. M., 35.135.21, McGraw-Hill, USA, 2001.

Lim, S. S., Vos, T., Flaxman, A. D., Danaei, G., Shibuya, K., Adair-Rohani, H., Amann, M., Anderson, H. R., Andrews, K. G., Aryee, M., Atkinson, C., Bacchus, L. J., Bahalim, A. N., Balakrishnan, K., Balmes, J., Barker-Collo, S., Baxter, A., Bell, M. L., Blore, J. D., Blyth, F., Bonner, C., Borges, G., Bourne, R., Boussinesq, M., Brauer, M., Brooks, P., Bruce, N. G., Brunekreef, B., Bryan-Hancock, C., Bucello, C., Buchbinder, R., Bull, F., Burnett, R. T., Byers, T. E., Calabria, B., Carapetis, J., Carnahan, E., Chafe, Z., Charlson, F., Chen, H., Chen, J. S., Cheng, A. T., Child, J. C., Cohen, A., Colson, K. E., Cowie, B. C., Darby, S., Darling, S., Davis, A., Degenhardt, L., Dentener, F., Des Jarlais, D. C., Devries, K., Dherani, M., Ding, E. L., Dorsey, E. R., Driscoll, T., Edmond, K., Ali, S. E., Engell, R. E., Erwin, P. J., Fahimi, S., Falder, G., Farzadfar, F., Ferrari, A., Finucane, M. M., Flaxman, S., Fowkes, F. G., Freedman, G., Freeman, M. K., Gakidou, E., Ghosh, S., Giovannucci, E., Gmel, G., Graham, K., Grainger, R., Grant, B., Gunnell, D., Gutierrez,
H. R., Hall, W., Hoek, H. W., Hogan, A., Hosgood III, H. D., Hoy, D., Hu, H., Hubbell, B. J., Hutchings, S. J., Ibeanusi, S. E., Jacklyn, G. L., Jasrasaria, R., Jonas, J. B., Kan, H., Kanis, J. A., Kassebaum, N., Kawakami, N., Khang, Y. H., Khatibzadeh, S., Khoo, J. P., Kok, C., Laden, F., Lalloo, R., Lan, Q., Lathlean, T., Leasher, J. L., Leigh, J., Li, Y., Lin, J. K., Lipshultz, S. E., London, S., Lozano, R., Lu, Y., Mak, J., Malekzadeh, R., Mallinger, L., Marcenes, W., March, L., Marks, R., Martin, R., McGale, P., McGrath, J., Mehta, S., Mensah, G. A., Merriman, T. R., Micha, R., Michaud, C., Mishra, V., Mohd Hanafiah, K., Mokdad, A. A., Morawska, L., Mozaffarian, D., Murphy, T., Naghavi, M., Neal, B., Nelson, P. K., Nolla, J. M., Norman, R., Olives, C., Omer, S. B., Orchard, J., Osborne, R., Ostro, B., Page, A., Pandey, K. D., Parry, C. D., Passmore, E., Patra, J., Pearce, N., Pelizzari, P. M., Petzold, M., Phillips, M. R., Pope, D., Pope III, C. A., Powles, J., Rao, M., Razavi, H., Rehfuess, E. A., Rehm, J. T., Ritz, B., Rivara, F. P., Roberts, T., Robinson, C., Rodriguez-Portales, J. A., Romieu, I., Room, R., Rosenfeld, L. C., Roy, A., Rushton, L., Salomon, J. A., Sampson, U., Sanchez-Riera, L., Sanman, E., Sapkota, A., Seedat, S., Shi, P., Shield, K., Shivakoti, R., Singh, G. M., Sleet, D. A., Smith, E., Smith, K. R., Stapelberg, N. J., Steenland, K., Stöckl, H., Stovner, L. J., Straif, K., Straney, L., Thurston, G. D., Tran, J. H., Van Dingenen, R., van Donkelaar, A., Veerman, J. L., Vijayakumar, L., Weintraub, R., Weissman, M. M., White, R. A., Whiteford, H., Wiersma, S. T., Wilkinson, J. D., Williams, H. C., Williams, W., Wilson, N., Woolf, A. D., Yip, P., Zielinski, J. M., Lopez, A. D., Murray, C. J., Ezzati, M., AlMazroa, M. A., and Memish, Z. A.: A comparative risk assessment of burden of disease and injury attributable to 67 risk factors and risk factor clusters in 21 regions, 1990-2010: a systematic analysis for the Global Burden of Disease Study 2010, Lancet, 380, 2224-2260, https://doi.org/10.1016/S0140-6736(12)617668, 2012.

Lu, S. H., Liu, Y., Shao, M., and Huang, S.: Chemical speciation and anthropogenic sources of ambient volatile organic compounds (VOCs) during summer in Beijing, Front. Environ. Sci. Eng. China, 1, 147-152, 2007.

Ma, P. K., Zhao, Y., Robinson, A. L., Worton, D. R., Goldstein, A. H., Ortega, A. M., Jimenez, J. L., Zotter, P., Prévôt, A. S. H., Szidat, S., and Hayes, P. L.: Evaluating the impact of new observational constraints on P-S/IVOC emissions, multigeneration oxidation, and chamber wall losses on SOA modeling for Los Angeles, CA, Atmos. Chem. Phys., 17, 9237-9259, https://doi.org/10.5194/acp-17-9237-2017, 2017.

Markakis, K., Im, U., Unal, A., Melas, D., Yenigun, O., and Incecik, S.: A computational approach for the compilation of a high spatially and temporally resolved emission inventory for the Istanbul Greater Area, in: Paper presented at the 7th International Conference of Air Quality Science and Application, Istanbul, 24-27 March 2009.

May, A. A., Nguyen, N. T., Presto, A. A., Gordon, T. D., Lipsky, E. M., Karve, M., Gutierrez, A., Robertson, W. H., Zhang, M., Brandow, C., Chang, O., Chen, S., Cicero-Fernandez, P., Dinkins, L., Fuentes, M., Huang, S.-M., Ling, R., Long, J., Maddox, C., Massetti, J., McCauley, E., Miguel, A., Na, K., Ong, R., Pang, Y., Rieger, P., Sax, T., Truong, T., Vo, T., Chattopadhyay, S., Maldonado, H., Maricq, M. M., and Robinson, A. L.: Gas- and particle-phase primary emissions from in-use, on- 
road gasoline and diesel vehicles, Atmos. Environ., 88, 247-260, https://doi.org/10.1016/j.atmosenv.2014.01.046, 2014.

McDonald, B. C., Gentner, D. R., Goldstein, A. H., and Harley, R. A.: Long-term trends in motor vehicle emissions in U.S. urban areas, Environ. Sci. Technol., 47, 10022-10031, https://doi.org/10.1021/es401034z, 2013.

McDonald, B. C., Goldstein, A. H., and Harley, R. A.: Long-term trends in California mobile source emissions and ambient concentrations of black carbon and organic aerosol, Environ. Sci. Technol., 49, 5178-5188, https://doi.org/10.1021/es505912b, 2015

Menut, L.: Adjoint modeling for atmospheric pollution process sensitivity at regional scale, J. Geophys. Res., 108, 8562, https://doi.org/10.1029/2002JD002549, 2003.

Miller, J. D. and Facanha, C.: The State of Clean Transport Policy - A 2014 Synthesis of Vehicle and Fuel Policy developments, International Council on Clean Transportation, Washington D.C., USA, 2014.

Ministry of Environmental Protection: Ambient air quality standards (GB 3095-2012), available at: http://kjs.mep.gov.cn/ hjbhbz/bzwb/dqhjbh/dqhjzlbz/201203/t20120302_224165.htm (last access: 13 April 2018), 2012.

Mitro, S. D., Dodson, R. E., Singla, V., Adamkiewicz, G., Elmi, A. F., Tilly, M. K., and Zota, A. R.: Consumer Product Chemicals in Indoor Dust: A Quantitative Meta-analysis of U.S. Studies, Environ. Sci. Technol., 50, 10661-10672, https://doi.org/10.1021/acs.est.6b02023, 2016.

Murphy, B. N., Donahue, N. M., Robinson, A. L., and Pandis, S. N.: A naming convention for atmospheric organic aerosol, Atmos. Chem. Phys., 14, 5825-5839, https://doi.org/10.5194/acp14-5825-2014, 2014.

National Research Council: Air Quality Management in the United States, National Academies Press, Washington, D.C., 2004.

Nazaroff, W. W. and Weschler, C. J.: Cleaning products and air fresheners: exposure to primary and secondary air pollutants, Atmos. Environ., 38, 2841-2865, https://doi.org/10.1016/j.atmosenv.2004.02.040, 2004.

Neligan, R. E.: Hydrocarbons in the Los Angeles atmosphere. A comparison between the hydrocarbons in automobile exhaust and those found in the Los Angeles atmosphere, Arch. Environ. Health, 5, 581-591, https://doi.org/10.1080/00039896.1962.10663334, 1962.

Ng, N. L., Kroll, J. H., Keywood, M. D., Bahreini, R., Varutbangkul, V., Flagan, R. C., Seinfeld, J. H., Lee, A., and Goldstein, A. H.: Contribution of first- versus second-generation products to secondary organic aerosols formed in the oxidation of biogenic hydrocarbons, Environ. Sci. Technol., 40, 2283-2297, https://doi.org/10.1021/es052269u, 2006.

Nielsen, O.-K., Winther, M., Mikkelsen, M. H., Hoffmann, L., Nielsen, M., Gyldenkærne, S., Fauser, P., Jensen, M. T., Plejdrup, M. S., and Illerup, J. B.: Annual Danish Emission Inventory Report to UNECE. Inventories from the base year of the protocols to year 2006, available at: http://www.dmu.dk/Pub/FR675.pdf (last access: 13 April 2018), 2008.

Pankow, J. F. and Asher, W. E.: SIMPOL.1: a simple group contribution method for predicting vapor pressures and enthalpies of vaporization of multifunctional organic compounds, Atmos. Chem. Phys., 8, 2773-2796, https://doi.org/10.5194/acp-8-27732008, 2008.
Parker, D., Sonne, J., and Sherwin, J.: Demonstration of Cooling Savings of Light Colored Roof Surfacing in Florida Commercial Buildings: Retail Strip Mall, Cocoa, Florida, 1997.

Pernigotti, D., Belis, C. A., and Spanò, L.: SPECIEUROPE: The European data base for PM source profiles, Atmos. Pollut. Res., 7, 307-314, https://doi.org/10.1016/j.apr.2015.10.007, 2016.

Piccot, S. D., Watson, J. J., and Jones, J. W.: A global inventory of volatile organic compound emissions from anthropogenic sources, J. Geophys. Res., 97, 9897-9912, https://doi.org/10.1029/92JD00682, 1992.

Platt, S. M., Haddad, I. El, Pieber, S. M., Huang, R.-J., Zardini, A. A., Clairotte, M., Suarez-Bertoa, R., Barmet, P., Pfaffenberger, L., Wolf, R., Slowik, J. G., Fuller, S. J., Kalberer, M., Chirico, R., Dommen, J., Astorga, C., Zimmermann, R., Marchand, N., Hellebust, S., Temime-Roussel, B., Baltensperger, U., and Prévôt, A. S. H.: Two-stroke scooters are a dominant source of air pollution in many cities., Nat. Commun., 5, 3749, https://doi.org/10.1038/ncomms4749, 2014.

Pomerantz, M., Pon, B., Akbari, H., and Chang, S.-C.: The Effect of Pavements' Temperatures on Air Temperatures in Large Cities, Berkeley, 2000.

Pope, C. A. I. and Dockery, D. W.: Health effects of fine particulate air pollution: lines that connect, J. Air Waste Manag. Assoc., 56, 709-742, 2006.

Poppendieck, D., Hubbard, H., Ward, M., Weschler, C., and Corsi, R. L.: Ozone reactions with indoor materials during building disinfection, Atmos. Environ., 41, 3166-3176, https://doi.org/10.1016/j.atmosenv.2006.06.060, 2007a.

Poppendieck, D. G., Hubbard, H. F., Weschler, C. J., and Corsi, R. L.: Formation and emissions of carbonyls during and following gas-phase ozonation of indoor materials, Atmos. Environ., 41, 7614-7626, https://doi.org/10.1016/j.atmosenv.2007.05.049, 2007b.

Pöschl, U. and Shiraiwa, M.: Multiphase Chemistry at the Atmosphere-Biosphere Interface Influencing Climate and Public Health in the Anthropocene, Chem. Rev., 115, 4440-4475, https://doi.org/10.1021/cr500487s, 2015.

Robinson, A. L., Donahue, N. M., Shrivastava, M. K., Weitkamp, E. A., Sage, A. M., Grieshop, A. P., Lane, T. E., Pierce, J. R., and Pandis, S. N.: Rethinking Organic Aerosols: Semivolatile Emissions and Photochemical Aging, Science, 315, 1259-1262, 2007.

Sadezky, A., Chaimbault, P., Mellouki, A., Römpp, A., Winterhalter, R., Le Bras, G., and Moortgat, G. K.: Formation of secondary organic aerosol and oligomers from the ozonolysis of enol ethers, Atmos. Chem. Phys., 6, 5009-5024, https://doi.org/10.5194/acp6-5009-2006, 2006.

Salthammer, T. and Fuhrmann, F.: Photocatalytic Surface Reactions on Indoor Wall Paint, Environ. Sci. Technol., 41, 6573-6578, https://doi.org/10.1021/ES070057M, 2007.

San Joaquin Valley Air Pollution Control District: 2008 Area Source Emissions Inventory Methodology 540 - ASPHALT PAVING, 2008.

Sarwar, G., Olson, D. A., Corsi, R. L., and Weschler, C. J.: Indoor Fine Particles: The Role of Terpene Emissions from Consumer Products, J. Air Waste Manage. Assoc., 54, 367-377, https://doi.org/10.1080/10473289.2004.10470910, 2004.

Shin, H.-M., McKone, T. E., and Bennett, D. H.: Contribution of low vapor pressure-volatile organic compounds (LVP-VOCs) from consumer products to ozone forma- 
tion in urban atmospheres, Atmos. Environ., 108, 98-106, https://doi.org/10.1016/j.atmosenv.2015.02.067, 2015.

Sillman, S.: The relation between ozone , NO and hydrocarbons in urban and polluted rural environments, Atmos. Environ., 33, 1821-1845, 1999.

Singer, B. C., Coleman, B. K., Destaillats, H., Hodgson, A. T., Lunden, M. M., Weschler, C. J., and Nazaroff, W. W.: Indoor secondary pollutants from cleaning product and air freshener use in the presence of ozone, Atmos. Environ., 40, 6696-6710, https://doi.org/10.1016/j.atmosenv.2006.06.005, 2006.

Song, Y., Shao, M., Liu, Y., Lu, S., Kuster, W., Goldan, P., and Xie, S.: Source apportionment of ambient volatile organic compounds in Beijing, Environ. Sci. Technol., 41, 4348-4353, 2007.

Sparks, L. E., Guo, Z., Chang, J. C., and Tichenor, B. A.: Volatile Organic Compound Emissions from Latex Paint - Part 2. Test House Studies and Indoor Air Quality (IAQ) Modeling, Indoor Air, 9, 18-25, https://doi.org/10.1111/j.1600-0668.1999.t01-300004.x, 1999.

Sullivan, D. A.: Water and solvent evaporation from latex and latex paint films, J. Paint Technol., 47, 60-67, 1975.

Tessum, C. W., Hill, J. D., and Marshall, J. D.: Life cycle air quality impacts of conventional and alternative light-duty transportation in the United States, P. Natl. Acad. Sci. USA, 111, 18490-18495, https://doi.org/10.1073/pnas.1406853111, 2014.

The Asphalt Institute: Asphalt Usage Survey for the United States and Canada, Asphalt Institute, Lexington, KY, USA, 2015.

The Asphalt Institute and European Bitumen Association: The bitumen industry: A global perspective: Production, chemistry, use, specification and occupational exposure, Asphalt Institute, Lexington KY USA, Eurobitume, Brussels, Belgium, 2015.

Toftum, J., Freund, S., Salthammer, T., and Weschler, C. J.: Secondary organic aerosols from ozone-initiated reactions with emissions from wood-based materials and a "green" paint, Atmos. Environ., 42, 7632-7640, https://doi.org/10.1016/j.atmosenv.2008.05.071, 2008.

Tsimpidi, A. P., Karydis, V. A., Zavala, M., Lei, W., Molina, L., Ulbrich, I. M., Jimenez, J. L., and Pandis, S. N.: Evaluation of the volatility basis-set approach for the simulation of organic aerosol formation in the Mexico City metropolitan area, Atmos. Chem. Phys., 10, 525-546, https://doi.org/10.5194/acp-10-5252010, 2010.

U.S. Environmental Protection Agency: 2011 National Emissions Inventory (NEI) Data, United States Environmental Protection Agency, Washington D.C., USA, 2011.

U.S. Environmental Protection Agency: SPECIATE 4.4. available at: https://www.epa.gov/air-emissions-modeling/ speciate-version-45-through-32 (last access: 13 April 2018), 2014.

U.S. Environmental Protection Agency and Office of Air Quality Planning and Standards: National Air Pollutant Emission Estimates 1940-1989, Research Triangle Park, North Carolina. available at: nepis.epa.gov/Exe/ZyPURL.cgi?Dockey= 00002PB0.TXT (last access: 13 April 2018), 1991.

U.S. EPA: Emissions Factors \& AP 42, Compilation of Air Pollutant Emission Factors, Volume 1: Stationary Point and Area Sources, Chapter 4: Evaporation Loss Sources, 1995.

U.S. EPA: Regulations for Emissions from Nonroad Vehicles and Engines, available at: https://www. epa.gov/regulations-emissions-vehicles-and-engines/ regulations-emissions-nonroad-vehicles-and-engines, last access: 15 August 2017.

van den Born, G. J., Bouwman, A. F., Oliver, J. G. J., and Swart, R. J.: The Emission of Greenhouse Gases in the Netherlands (Report no. 222901003), the Netherlands, 1991.

von Schneidemesser, E., Coates, J., Denier van der Gon, H. A. C., Visschedijk, A. J. H., and Butler, T. M.: Variation of the NMVOC speciation in the solvent sector and the sensitivity of modelled tropospheric ozone, Atmos. Environ., 135, 59-72, https://doi.org/10.1016/j.atmosenv.2016.03.057, 2016.

Warneke, C., de Gouw, J. A., Holloway, J. S., Peischl, J., Ryerson, T. B., Atlas, E., Blake, D., Trainer, M., and Parrish, D. D.: Multiyear trends in volatile organic compounds in Los Angeles, California: Five decades of decreasing emissions, J. Geophys. Res.-Atmos., 117, D00V17, https://doi.org/10.1029/2012JD017899, 2012.

Washenfelder, R. A., Young, C. J., Brown, S. S., Angevine, W. M., Atlas, E. L., Blake, D. R., Bon, D. M., Cubison, M. J., de Gouw, J. A., Dusanter, S., Flynn, J., Gilman, J. B., Graus, M., Griffith, S., Grossberg, N., Hayes, P. L., Jimenez, J. L., Kuster, W. C., Lefer, B. L., Pollack, I. B., Ryerson, T. B., Stark, H., Stevens, P. S., and Trainer, M. K.: The glyoxal budget and its contribution to organic aerosol for Los Angeles, California, during CalNex 2010, J. Geophys. Res.-Atmos., 116, D00V02, https://doi.org/10.1029/2011JD016314, 2011.

Weiss, M., Bonnel, P., Hummel, R., Provenza, A., and Manfredi, U.: On-Road Emissions of Light-Duty Vehicles in Europe, Environ. Sci. Technol., 45, 8575-8581, https://doi.org/10.1021/es2008424, 2011.

Wensing, M., Uhde, E., and Salthammer, T.: Plastics additives in the indoor environment - flame retardants and plasticizers, Sci. Total Environ., 339, 19-40, https://doi.org/10.1016/j.scitotenv.2004.10.028, 2005.

Weschler, C. J.: Chemistry in indoor environments: 20 years of research, Indoor Air, 21, 205-218, https://doi.org/10.1111/j.16000668.2011.00713.x, 2011.

Weschler, C. J. and Nazaroff, W. W.: Semivolatile organic compounds in indoor environments, Atmos. Environ., 42, 90189040, https://doi.org/10.1016/j.atmosenv.2008.09.052, 2008.

Weschler, C. J. and Nazaroff, W. W.: SVOC partitioning between the gas phase and settled dust indoors, Atmos. Environ., 44, 3609-3620, https://doi.org/10.1016/j.atmosenv.2010.06.029, 2010.

Wilke, O., Jann, O., and Brodner, D.: VOC- and SVOC-emissions from adhesives, floor coverings and complete floor structures, Indoor Air, 14, 98-107, https://doi.org/10.1111/j.16000668.2004.00314.x, 2004.

Wolkoff, P.: Impact of air velocity, temperature, humidity, and air on long-term voc emissions from building products, Atmos. Environ., 32, 2659-2668, https://doi.org/10.1016/S13522310(97)00402-0, 1998.

Xu, L., Guo, H., Boyd, C. M., Klein, M., Bougiatioti, A., Cerully, K. M., Hite, J. R., Isaacman-VanWertz, G., Kreisberg, N. M., Knote, C., Olson, K., Koss, A., Goldstein, A. H., Hering, S. V, de Gouw, J., Baumann, K., Lee, S.-H., Nenes, A., Weber, R. J., and $\mathrm{Ng}$, N. L.: Effects of anthropogenic emissions on aerosol formation from isoprene and monoterpenes in the southeastern United States, P. Natl. Acad. Sci. USA, 112, 37-42, https://doi.org/10.1073/pnas.1417609112, 2015. 
Zhang, Q., Jimenez, J. L., Canagaratna, M. R., Allan, J. D., Coe, H., Ulbrich, I., Alfarra, M. R., Takami, A., Middlebrook, A. M., Sun, Y. L., Dzepina, K., Dunlea, E., Docherty, K., DeCarlo, P. F., Salcedo, D., Onasch, T., Jayne, J. T., Miyoshi, T., Shimono, A., Hatakeyama, S., Takegawa, N., Kondo, Y., Schneider, J., Drewnick, F., Borrmann, S., Weimer, S., Demerjian, K., Williams, P., Bower, K., Bahreini, R., Cottrell, L., Griffin, R. J., Rautiainen, J., Sun, J. Y., Zhang, Y. M., and Worsnop, D. R.: Ubiquity and dominance of oxygenated species in organic aerosols in anthropogenically-influenced Northern Hemisphere midlatitudes, Geophys. Res. Lett., 34, L13801, https://doi.org/10.1029/2007GL029979, 2007.

Zhao, Y., Hennigan, C. J., May, A. A., Tkacik, D. S., De Gouw, J. A., Gilman, J. B., Kuster, W. C., Borbon, A., and Robinson, A. L.: Intermediate-Volatility Organic Compounds: A Large Source of Secondary Organic Aerosol, Environ. Sci Technol., 48, 13743-13750, https://doi.org/10.1021/es5035188, 2014.

Zhao, Y., Nguyen, N. T., Presto, A. A., Hennigan, C. J., May, A. A., and Robinson, A. L.: Intermediate Volatility Organic Compound Emissions from On-road Gasoline Vehicles and Small Off-road Gasoline Engines, Environ. Sci. Technol., 50, 4554-4563, 2016.
Zhao, Y., Saleh, R., Saliba, G., Presto, A. A., Gordon, T. D., Drozd, G. T., Goldstein, A. H., Donahue, N. M., and Robinson, A. L.: Reducing secondary organic aerosol formation from gasoline vehicle exhaust, P. Natl. Acad. Sci. USA, 114, 6984-6989, https://doi.org/10.1073/pnas.1620911114, 2017.

Zhou, Y., Levy, J. I., Hammitt, J. K., and Evans, J. S.: Estimating population exposure to power plant emissions using CALPUFF: a case study in Beijing, China, Atmos. Environ., 37, 815-826, https://doi.org/10.1016/S1352-2310(02)00937-8, 2003.

Zotter, P., El-Haddad, I., Zhang, Y., Hayes, P. L., Zhang, X., Lin, Y.-H., Wacker, L., Schnelle-Kreis, J., Abbaszade, G., Zimmermann, R., Surratt, J. D., Weber, R., Jimenez, J. L., Szidat, S., Baltensperger, U., and Prévôt, A. S. H.: Diurnal cycle of fossil and nonfossil carbon using radiocarbon analyses during CalNex, J. Geophys. Res.-Atmos., 119, 6818-6835, https://doi.org/10.1002/2013JD021114, 2014. 